\title{
Remote-sensing systems and seabirds: their use, abuse and potential for measuring marine environmental variables
}

\author{
Rory P. Wilson ${ }^{1, *}$, David Grémillet ${ }^{1,6}{ }^{,}$Jon Syder $^{2}$, Mandy A. M. Kierspel ${ }^{1}$, \\ Stefan Garthe $^{1}$, Henri Weimerskirch ${ }^{3}$, Christian Schäfer-Neth ${ }^{4}$, J. Alejandro Scolaro ${ }^{5}$, \\ Charles-André Bost ${ }^{6}$, Joachim Plötz ${ }^{7}$, Deon Nel ${ }^{8}$ \\ ${ }^{1}$ Institut für Meereskunde, Düsternbrooker Weg 20, 24105 Kiel, Germany \\ ${ }^{2}$ Hydrology Program, Department of Land, Air and Water resources, University of California, Davis, \\ California 95616-8628, USA \\ ${ }^{3}$ Centre d'Etudes Biologiques de Chizé, Centre National de la Recherche Scientifique, 79360 Beauvoir/Niort, France \\ ${ }^{4}$ Universität Bremen, FB2 - Meereschemie, Postfach 330440, 28334 Bremen, Germany \\ ${ }^{5}$ Centro Patagonico, Boulevard Brown s/n, Puerto Madryn, Chubut, Argentina \\ ${ }^{6}$ Centre d'Ecologie et Physiologie Energétiques, Centre National de la Recherche Scientifique, 23 rue Becquerel, \\ 67087 Strasbourg, France \\ ${ }^{7}$ Alfred Wegener Institut, Columbusstraße, 27568 Bremerhaven, Germany \\ ${ }^{8}$ FitzPatrick Institute, University of Cape Town, Rondebosch, 7700, South Africa
}

\begin{abstract}
We examined how seabirds might be used to study marine environmental variables, which necessitates knowing location and the value of the variable to be studied. Five systems can potentially be used for determination of location: VHF (Very High Frequency) telemetry, PTT (Platform Terminal Transmitters) telemetry, GLS (Global Location Service) geolocation methods, dead reckoning and GPS (Global Positioning System), each with its own advantages with respect to accuracy, potential number of fixes and size. Temperature and light were used to illustrate potential difficulties in recording environmental variables. Systems currently used on seabirds for measurement of temperature respond slowly to environmental changes; thus, they may not measure sea surface temperature adequately when contact periods with water bodies are too short. Light can be easily measured for light extinction studies, but sensor orientation plays a large role in determining recorded values. Both problems can be corrected. The foraging behaviour of seabirds was also examined in order to identify those features which would be useful for determination of marine environmental variables at a variety of spatial and temporal scales. Area coverage by birds is highly dependent on breeding phase and tends to be concentrated in areas where prey acquisition is particularly enhanced. The identification of these sites may be of particular interest to marine biologists. 'Plungers' and 'divers' are potentially most useful for assessment of variables deeper within the water column, with some divers spending up to $90 \%$ of their time sub-surface. Few seabirds exploit the water column deeper than $20 \mathrm{~m}$, although some divers regularly exceed $50 \mathrm{~m}$ (primarily penguins and auks), while 2 species dive in excess of $300 \mathrm{~m}$. The wide-ranging behaviour of seabirds coupled, in many instances, with their substantial body size makes them potentially excellent carriers of sophisticated environmental measuring technology; however, the ethical question of how much the well-being of birds can, and should, be compromised by such an approach needs to be carefully considered.
\end{abstract}

KEY WORDS: Seabirds $\cdot$ Monitoring $\cdot$ Oceanographic variables $\cdot$ SST $\cdot$ Light extinction

\section{INTRODUCTION}

The intimate relationship between many marine endotherms and the sea has prompted some workers to

*E-mail: rwilson@ifm.uni-kiel.de suggest that aspects of the oceans can be elucidated by studying the endotherms themselves. For example, studies of seabird feeding habits, growth rates and survival have been related to local prey abundance (e.g. Cairns 1987, Montevecchi 1993, Monaghan 1996, Montevecchi \& Myers 1996) and both marine mam- 
mals and seabirds have been used to examine the extent of pollutants in areas utilised by the animals (e.g. Furness \& Camphuysen 1997, Mossner \& Ballschmitter 1997, Beckmen et al. 1999, Hunt et al. 1999). However, recent advances in solid state technology have made it possible to equip many marine endotherms with devices during their forays at sea so as to determine animal movements and habits (e.g. Bost et al. 1997, McCafferty et al. 1999), and, in a further refinement of the technology, it is now possible to measure some environmental variables with these devices (e.g. Weimerskirch et al. 1995). As a result of this, it has been suggested that marine endotherms, appropriately equipped, could be used to measure and monitor the physical properties of the oceans in which they forage, with specific localities being ascribed specific measurements (e.g. Wilson 1992, 1999, Wilson et al. 1993, Weimerskirch et al. 1995, Boyd 1997, Campaña et al. 2000, Georges et al. 2000, Koudil et al. 2000). Although this concept is gaining in popularity, there has never been any critical assessment of the features necessary in the technology to make the concept genuinely feasible, nor has the behaviour of marine endotherms been examined in detail to assess what features of their behaviour might prove advantageous for such a purpose.

This paper considers some of the tools available for studying the foraging behaviour of seabirds: we consider potential sources of error in proposed positiondetermining systems used on free-living marine endo- therms and consider the types of error that might be incurred by using sensors to measure environmental variables. We examine selected information in order to present how marine endotherm behaviour leads the animals to sample specific volumes of the ocean. Finally, we briefly consider rough guidelines regarding the ethics of equipping animals with remotesensing technology with a view to elucidating aspects of ocean ecology. This work is not intended to be an exhaustive review and, for the sake of brevity in a broad field, we have limited ourselves to seabirds, relying heavily on our own work, some of which has not been previously published. This gives readers a chance to assess the potential in recently developed systems or systems that have, as yet, no commercial outlet.

\section{MATERIALS AND METHODS}

Rather than give an exhaustive list of all the localities, species and techniques covered by the multiple authors, we present a brief overview below and refer to details, where relevant, later in the text. The field work which provides the basis for this paper was conducted between 1987 and 1999 at various sites in and around Antarctica (including sub-Antarctic islands), Argentina, South Africa and the UK on 14 species of seabirds (Table 1) (see also, e.g. Wilson et al. 1993, Weimerskirch 1998a, Grémillet et al. 2000). Birds were

Table 1. Species of seabirds used during the course of the study, the technology used on them (see Table 2 for details — names of the devices are trade names) and the localities at which they were studied

\begin{tabular}{|c|c|c|}
\hline Species & Locality & Unit \\
\hline Adélie penguin Pygoscelis adeliae & Ardley Island $\left(62^{\circ} 13^{\prime} \mathrm{S}, 58^{\circ} 55^{\prime} \mathrm{W}\right)$ & DK 101, DK 600, Pillbox GLS \\
\hline African penguin Spheniscus demersus & Dassen Island $\left(33^{\circ} 25^{\prime} \mathrm{S}, 18^{\circ} 05^{\prime} \mathrm{E}\right)$ & DK 101 \\
\hline Chinstrap penguin Pygoscelis antartica & Ardley Island & DK 101, DK 600, Pillbox GLS \\
\hline Gentoo penguin Pygoscelis papua & $\begin{array}{l}\text { Ardley Island } \\
\text { Possession Island }\left(46^{\circ} 25^{\prime} \mathrm{S}, 51^{\circ} 40^{\prime} \mathrm{E}\right)\end{array}$ & $\begin{array}{l}\text { DK 101, Pillbox GLS } \\
\text { DK } 101\end{array}$ \\
\hline King penguin Aptenodytes patagonicus & $\begin{array}{l}\text { Possession Island } \\
\text { Kerguelan Islands }\left(50^{\circ} \mathrm{S}, 66^{\circ} 02^{\prime} \mathrm{W}\right)\end{array}$ & $\begin{array}{l}\text { ST10, T2038, MkV } \\
\text { ST10, T2038 }\end{array}$ \\
\hline Magellanic penguin Spheniscus magellanicus & $\begin{array}{l}\text { Argentina }\left(49^{\circ} 16^{\prime} \mathrm{S}, 67^{\circ} 43^{\prime} \mathrm{E}\right) \\
\text { Falkland Islands }\end{array}$ & $\begin{array}{l}\text { Pillbox GLS, DK } 600 \\
\text { DK 600, Zelcon, ST10 }\end{array}$ \\
\hline Macaroni penguin Eudyptes chrysolophus & Possession Island & DK 101 \\
\hline Wandering albatross Diomedea exulans & $\begin{array}{l}\text { Possession Island } \\
\text { Marion Island }\end{array}$ & $\begin{array}{l}\text { Pillbox TP, ST10 } \\
\text { ST10, Pillbox GLS, LTD } 100\end{array}$ \\
\hline Grey-headed albatross Diomedea chrysostoma & Marion Island & ST10, Pillbox GLS \\
\hline Black-browed albatross Diomedea melanophris & Falkland Islands & DST 100, Zelcon, DK 600 \\
\hline Northern fulmar Fulmarus glacialis & Foula $\left(60^{\circ} 08^{\prime} \mathrm{N}, 2^{\circ} 05^{\prime} \mathrm{W}\right)$ & LTD 100 \\
\hline Northern gannet Sula bassana & Hermaness $\left(60^{\circ} 50^{\prime} \mathrm{N}, 0^{\circ} 55^{\prime} \mathrm{W}\right)$ & Onset, LTD 100 \\
\hline Great cormorant Phalacrocorax carbo & French Islands $\left(48^{\circ} 55^{\prime} \mathrm{N}, 1^{\circ} 45^{\prime} \mathrm{W}\right)$ & TW3 \\
\hline European shag Phalacrocorax aristotelis & French Islands & TW3 \\
\hline
\end{tabular}


variously equipped with position-determining units and dataloggers (Table 2).

Position-determining units. VHF transmitters were TW3 2-stage transmitters equipped with 2 aerials (Biotrack; mass $18 \mathrm{~g}$, $30 \mathrm{~mm}$ long $\times 20 \mathrm{~mm}$ diam. with main and secondary aerials 280 and $230 \mathrm{~mm}$ long, respectively), with a mean pulse rate of 1.3 pulses $\mathrm{s}^{-1}$.

The platform terminal transmitters (PTTs) that have been used on seabirds were built by 2 major companies: Toyocom and Microwave. Since 1989, when the first PTTs were used on seabirds (Toyocom T2028, $180 \mathrm{~g})$ progressive miniaturisation in solid state electronics has resulted in current PTTs that are on the order of $20 \mathrm{~g}$ (for volant seabirds: Microwave). These PTTs are powered by lithium batteries or solar panels and transmit a signal every 60 to 90 s continuously, but can be duty cycled, i.e. programmed to be switched off for determined periods to allow a longer lifespan of the batteries. Location of these PTTs is provided by the Argos System (Argos CLS, Toulouse, France).

Global Location System sensors (GLSs) or geolocating devices were used as simple, single-channel loggers or as part of multiple-channel loggers incorporating other features. The single-channel loggers were based on the 'pillbox' logger (Driesen \& Kern), which recorded data within the approximate range of 0.1 to 25 lux in a $128 \mathrm{~kb}$ memory with 8 bit resolution, using a photoelectric sensor covered by a BG 28 blue filter (Schott Glaswerke) which limited the wavelength of the light activating the sensor to the deep blue region where light is least attentuated by cloud cover (see Wilson et al. in press). The unit was encapsulated in resin and recorded at intervals of between 8 and $128 \mathrm{~s}$.

All position-determining units were attached to birds by using waterproof, cloth-backed Tesa tape (Wilson et al. 1997), at 1 of 3 sites: to a Darvic ring placed around the leg; to feathers in the centre of birds' backs (dorsal, mid-line), except in the case of penguins, where the units were placed posterior to this, following suggestions in Bannasch et al. (1994), or to tail feathers (Wanless et al. 1991). Maximum wearing times for the various methods were up to 8 mo for the rings, 3 mo for the back feathers and 2.5 mo for the tail feathers.

Environmental variables. Except for GLS applications (see above), we used 2 types of single-channel loggers, both to measure temperature (Wilson et al. 1995c) (Table 2). Both units were attached by using waterproof, cloth-backed Tesa tape (Wilson et al. 1997) to attach them to Darvic rings placed on birds' legs, for wearing periods of up to 2 mo.

We used a total of 6 types of multiple-channel loggers with various hardware formats; details are listed in Table 2. Where the units were used as GLSs, all light sensors were covered with a BG 28 blue filter (Schott

Table 2. Features of the PTTs, VHF transmitters and single and multiple channel loggers used in the course of this work. Variables measured: $D=$ depth$_{i} H=$ heading; $L=\operatorname{light} P=$ position$_{i} S=$ speed $T=$ temperature

\begin{tabular}{|c|c|c|c|c|c|c|}
\hline Unit & Manufacturer & Variables & Resolution & Memory & Size $(\mathrm{mm})$ & Mass $(g)$ \\
\hline \multicolumn{7}{|l|}{ Loggers } \\
\hline DK 101 & $\begin{array}{l}\text { Driesen \& Kern, } \\
\text { Bad Bramstedt, Germany }\end{array}$ & $L, T, S, D, H$ & $8-10$ bit & $32-64 \mathrm{~kb}$ & $200 \times 22 \times 65$ & 200 \\
\hline DK 600 & Driesen \& Kern & $L, T, S, D, H$ & 16 bit & $2 \mathrm{Mb}$ & $145 \times 20 \times 65$ & 110 \\
\hline Pillbox GLS & Driesen \& Kern & $L$ & 8 bit & $128 \mathrm{~kb}$ & $125 \times 38 \times 25$ & 42 \\
\hline Pillbox TP & Driesen \& Kern & $T$ & 8 bit & $128 \mathrm{~kb}$ & $70 \times 18$ (diam.) & 35 \\
\hline LTD 100 & $\begin{array}{l}\text { Lotek; } \\
\text { St. Johns, Canada }\end{array}$ & $L, T, D$ & 12 bit & $1.5 \mathrm{Mb}$ & $44 \times 18$ (diam.) & 16 \\
\hline Onset & $\begin{array}{l}\text { Onset Computer, } \\
\text { Pocasset, MA, USA }\end{array}$ & $T$ & 8 bit & $32 \mathrm{~kb}$ & $41 \times 30 \times 17$ & 23 \\
\hline Mk V & $\begin{array}{l}\text { Wildlife Computers, } \\
\text { Redmond, WA, USA }\end{array}$ & $L, T, D$ & 8 bit & $512 \mathrm{~kb}$ & $62 \times 35 \times 13$ & 75 \\
\hline Mk VI & Wildlife Computers & $L, T, D, S$ & 8 bit & $512 \mathrm{~kb}$ & $73 \times 55 \times 36$ & 120 \\
\hline Zelcon & $\begin{array}{l}\text { Zelcon Technic, } \\
\text { Glenorchy, Australia }\end{array}$ & $L, T, D$ & 8 bit & $1 \mathrm{Mb}$ & $55 \times 24 \times 12$ & 25 \\
\hline \multicolumn{7}{|l|}{ PTTs } \\
\hline T2038 & $\begin{array}{l}\text { Toyocom, } \\
\text { Tokyo, Japan }\end{array}$ & $P$ & & & $105 \times 35 \times 18$ & 55 \\
\hline ST10 & $\begin{array}{l}\text { Microwave Telemetry, } \\
\text { Columbia, MD, USA }\end{array}$ & $P$ & & & $90 \times 42 \times 17$ & 85 \\
\hline \multicolumn{7}{|c|}{ VHF transmitters } \\
\hline TW3 & $\begin{array}{l}\text { Biotrack, } \\
\text { Wareham, UK }\end{array}$ & $P$ & & & $30 \times 20$ diam & 18 \\
\hline
\end{tabular}


Glaswerke), and light values were stored at intervals ranging between 2 and $120 \mathrm{~s}$ within the approximate range of 0.1 to 80000 lux.

Variables monitored by the loggers were resolved by $8,10,12$ or 16 bits in memories ranging between $32 \mathrm{~kb}$ and $2 \mathrm{Mb}$ (Table 2). In addition to light, these variables were:

- temperature within the range 0 to $50^{\circ} \mathrm{C}$

- depth (via hydrostatic pressure) within the range 2 to 40 bar,

- flight height (via air pressure) to a maximum of 1.5 bar absolute pressure,

- swim or flight speed (via diffential pressure using a Prandl tube) within the range 0.001 to 1 bar,

- direction using a miniature magnetic ship's compass where the orientation of the unit with respect to that of the bird is sensed by Hall sensors (Hochscheid \& Wilson 1999)

More specific details regarding the characteristics of the units attached to birds are given in Weimerskirch et al. (1992, 1993) and Weimerskirch $(1998 a, b)$ for PTTs, Grémillet et al. (1999) for VHF transmitters, Wilson et al. (in press) for GLSs and in Wilson et al. $(1993,1995 \mathrm{c})$ for the loggers.

Multiple-channel loggers were either attached to Darvic rings on birds' legs using tape (Wilson et al. 1997) or were attached to birds' backs by taping them to feathers (Wilson et al. 1997). Wearing periods for both leg-attached as well as back-attached units were up to $8 \mathrm{mo}$.

\section{RESULTS AND DISCUSSION}

To use seabirds as effective monitors of the marine environment 3 major issues are of relevance: the quality of the positional fixes, the quality of the environmental data gathered by the birds and the utility of the sampling regime that the birds provide by virtue of their behaviour.

\section{Quality of positional fixes}

\section{Geographic location}

There are 4 major methods for determination of seabird geographic location currently being used (VHF transmitters, satellite transmitters, global location sensors, dead reckoners) and a fifth that is likely to be implemented within the next 2 yr (Global Positioning System, GPS).

VHF transmitters. VHF transmitters (e.g. Kenward 1987) have been used extensively on seabirds since the 1970s (e.g. Morris \& Black 1980, Wanless et al. 1991) and are of limited application since they require that receiving units remain within sight contact of the transmitters. This has meant that researchers have only deployed such systems with inshore species (e.g. Grémillet et al. 1999) or have had to go to considerable trouble to follow birds at sea with mobile receiving units, something that is only practicable with slowly moving species such as penguins (e.g. Heath \& Randall 1989). In addition, radio waves are not transmitted appreciably through seawater, so species that spend much time diving, or foraging in areas where the swell is substantial, can be problematic (but see Wanless \& Harris 1992). The overall maximum range of a shorebased, radio-tracking system is approximately $50 \mathrm{~km}$ (D.G. unpubl. data). This can be substantially increased if mobile receiving units are used (e.g. Heath \& Randall 1989), but such steps are generally costly and labour intensive. The overall reception quality, irrespective of whether the receiving unit is mobile or stationary, is not only dependent on the curvature of the earth and the merit of the receiving unit, but also on local topography and mineralogy as well as local radio traffic and interference from, for example, the proximity of 2-stroke engines (Kenward 1987, D.G. unpubl. data). The suitability of a particular area for radio-telemetry studies is therefore best decided in trials on site. The bearings recorded at 2 separate tracking stations are usually combined to estimate the at-sea position of the equipped animal using triangulation. The overall accuracy of the acquired position can be assessed using error polygons, whereby the errors in the 2 bearings (each typically between 2 and $5^{\circ}$; cf. Kato et al. 1998) are calculated into arcs, the width of each of which increases with the distance between transmitter and receiver (see White \& Garrott 1990). The width of the arcs at the point where the 2 bearings overlap determines the size of the error polygon, which becomes greater the more acute the angle between the 2 bearings is (White \& Garrott 1990). Errors in positional estimation of seabirds are typically of the order of $2 \mathrm{~km}$ (e.g. Kato et al. 1998). The surface area of each polygon, which describes the area within which the bird is situated, as well as its travelling speed, determines the rate at which fixes can be effectively taken. This rate, therefore, may vary from a few seconds during fast power flight (up to $18 \mathrm{~m} \mathrm{~s}^{-1}$; Pennycuick 1997) up to several hours in flightless offshore species. The use of 3 or more tracking stations instead of the usual 2 may help detect erroneous bearings, but is unlikely to increase the overall accuracy of the system significantly (White \& Garrott 1990).

Satellite tracking transmitters. PTTs have proved invaluable for determination of the movements of farranging seabirds, in particular albatrosses (see review in Weimerskirch 1998a, see also Benvenuti 1993) 
although smaller birds that forage less widely have also been equipped (e.g. Peterson \& Douglas 1994, Falk \& Moller 1995, Meyers et al. 1998). Radio-signals transmitted by the units are received and localised by orbiting satellites so that the foraging range does not affect the ability to obtain a positional fix. However, currently the sole PTT service is based on the Argos receiving system placed on satellites with a polar orbit, which means that the number of passes effected per day, when a PTT at a particular position can be localised, is greater at the poles (28 passes) than at the equator (8 passes) (Taillade 1992, Argos User Manual 2000). In addition, as with VHF transmitters, there is no signal transmission when the unit is underwater so that species that spend much time diving generate a substantially lower rate of positional fixes than non-divers (cf. Davis \& Miller 1992, Bost et al. 1997, Hull et al. 1997). Similarly, the number of satellite passes over a particular location is not constant per unit time so that the number of locations may be substantially lower at some times than at others (Georges et al. 1997). This means that even if the study animal is accessible to the satellite at all times, such as is nominally the case in non-divers, the movements of the animal cannot be determined at regular intervals.

The Argos system (Service Argos 1996) provides 7 classes of accuracy, in order of decreasing accuracy from 3, 2, 1, 0, A, B to Z. Argos gives an accuracy (within $1 \mathrm{SD}$ ) for 4 classes (Class $3=150 \mathrm{~m}$, Class $2=$ $350 \mathrm{~m}$, Class $1=1 \mathrm{~km}$, Class $0>1 \mathrm{~km})$. A, B and Z have no specified accuracy. The quality of the fixes and the proportion of each quality fix depend on several factors, among others, the manufacturer, the model of PTT, the power of the transmissions, and the speed of the animal (Weimerskirch et al. 1992) or its behaviour (diving or flying). Independent tests of PTT accuracy with the PTT at a fixed and known location have been performed to assess the error (Weimerskirch et al. 1992, Brothers et al. 1998), and indicate that average error values are poorer than those provided by the system for the locations 3 and 2 (300 and $500 \mathrm{~m}$ on average) but close to predicted values for locations of Class 1 . The accuracy of the other location fixes is very variable, being very high for some locations and very poor for others. This sort of analysis does not, however, accurately reflect the quite different conditions necessitated when a positional fix has to be derived from a flying or diving bird. Burns \& Castellini (1998) considered the quality of satellite tracking fixes derived from free-living Weddell seals Leptonychotes weddellii by comparing it with simultaneously derived GPS fixes (see later). They found that the actual accuracy was considerably worse than that given by Argos, with Classes 0 and 1 fixes having mean errors of 11.4 and $5.0 \mathrm{~km}$, respectively, with errors in latitude being greater than those of longitude. In the case of the Class 1 fixes, this is an error of some $500 \%$ more than that stipulated by Argos (Service Argos predicts that $68 \%$ of all Class 1 fixes should fall within $1 \mathrm{~km}$ of the true location; Service Argos 1996).

Global Location Service sensors/geolocation. GLS sensors have been used only relatively recently and were developed to answer to 2 principle needs: as an alternative to satellite tracking systems for species which spend insufficient time at the surface to get reliable position fixes (Delong et al. 1992, Block et al. 1998), and for deployment on species which are considered too small to carry the rather bulky PTTs. Many GLS sensors used today weigh under $20 \mathrm{~g}$, and there is considerable room for improvement because no power pack or aerial is needed for transmission telemetry. These systems log light intensity at regular intervals for extended periods on a highly accurate Greenwich mean time (GMT) time base. Upon retrieval of the unit, the light intensity values are used to determine the local times of dawn and dusk which are used to derive daylength and local time of midday and midnight as a function of the day of the year. Daylength can then be used to derive latitude and the local time of midday or midnight used to derive longitude (Wilson et al. 1992a, in press, Hill 1994, Welch \& Eveson 1999). The process allows 2 fixes per $24 \mathrm{~h}$, one taken to be the bird's position at midday and the other at midnight, with no latitude fixes possible for between 10 and $21 \mathrm{~d}$ on either side of the equinox. Recent algorithms used to derive position take into account potential changes in bird position between dawn and dusk and vice versa by considering the total day plus night length which should be ca. $24 \mathrm{~h}$ if the bird has moved little and need to be corrected if birds move extensively (Wilson et al. in press). The accuracy of positional fixes is much lower than that achieved by satellite telemetry and dependent on a number of environmental and animal-dependent variables such as cloud cover, diving behaviour of the animal around dawn and dusk and light sensor orientation at the time measurements are made. Many errors can be reduced by measures such as by using filters to cover the sensor or by smoothing data during analysis (Wilson et al. in press). Nonetheless, logging light intensity once every $60 \mathrm{~s}$, and using an algorithm presented in Wilson et al. (in press) we achieved a mean maximum positional accuracy of $18.8 \mathrm{~km}$ (SD = $13.2, \mathrm{n}=78$ ) from ideally placed, stationary GLSs. The overall accuracy of GLS sensors on free-living animals is difficult to assess because packages involving 2 position-determining units are generally unacceptably large (cf. Bannasch et al. 1994). However, when we placed GLSs simultaneously with PTTs on a King penguin Aptenodytes patagonicus foraging from Possession Island, southern Indian Ocean, we achieved a 
mean concordance (difference between the position calculated by the PTT and the GLS) of $31.3 \mathrm{~km}$ (SD $30.6, \mathrm{n}=13$ ), even though these birds spend a large proportion of the time around dawn and dusk underwater (Pütz et al. 1998), which makes position determination less accurate (Wilson et al. in press). In addition, based on consideration of known swim speeds and deviations from a straight line course, similar units placed on foraging Magellanic penguins Spheniscus magellanicus from Peninsula Valdes, Argentina, were considered to give an accuracy better than $40 \mathrm{~km}$ (Wilson et al. 1995b). Finally, grey-headed albatross Diomedea chrysostoma foraging from Marion Island, southern Indian Ocean, essentially all foraged in the same sector of the ocean irrespective of whether they were tracked with PTTs or GLSs (Nel et al. 2000).

It is important, however, to note that the determination of positional accuracy using GLS methodology is
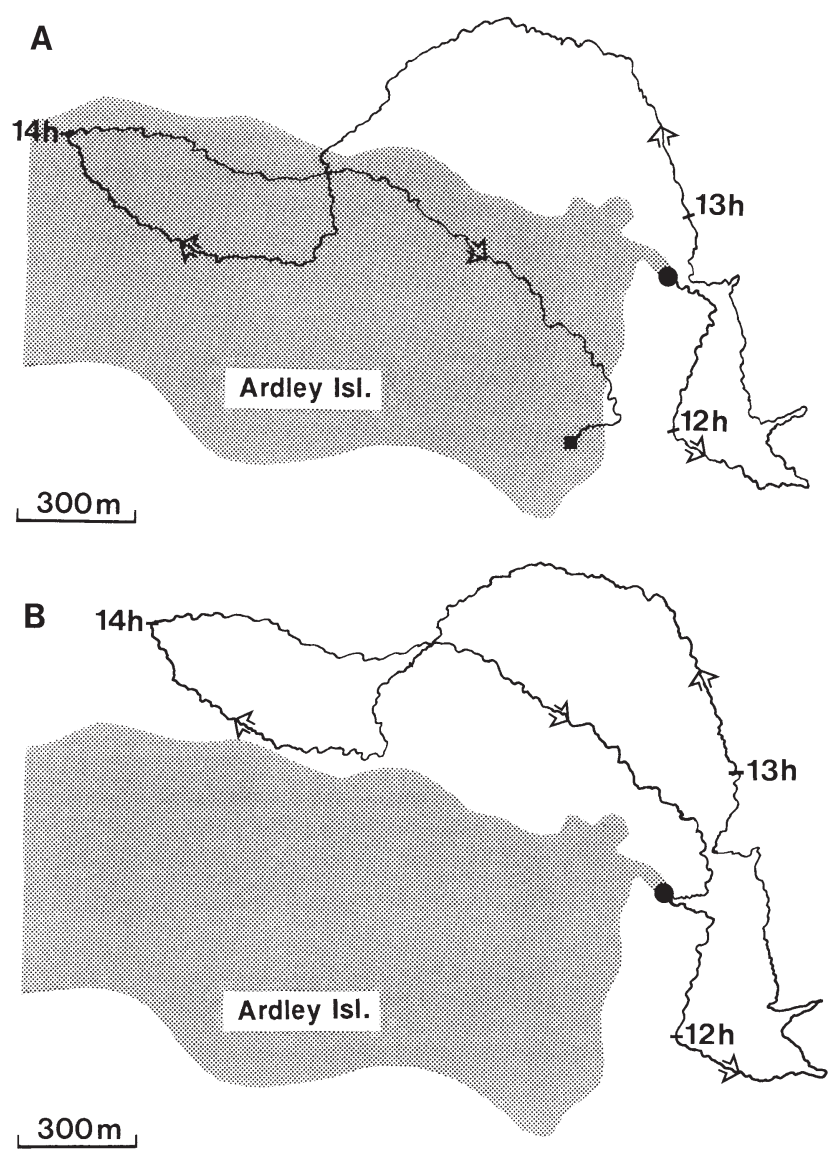

Fig. 1. Example of the foraging track of a gentoo penguin Pygoscelis papua as determined by dead reckoning, showing the data (B) with and (A) without drift correction. Errors incurred by drift were assumed to be due to a constant current pushing the bird in a south-westerly direction for the whole duration of the foraging trip, and data were corrected accordingly only as good as the hardware to determine light intensity and the positioning of the sensor such that it can perceive light appropriately. Recent trials with miniature devices on wandering albatross Diomeda exulans legs (Weimerskirch \& Wilson 2000) showed that errors could be as high as $200 \mathrm{~km}$.

Dead reckoning. Dead reckoning is another technique used to determine animal movements. It is based on determination of animal speed, heading and changes in vertical position (i.e. depth) in an animalattached archival unit. Vectorial calculations on these values, together with known information on the start (and end) position of the bird allow reconstruction of the route taken by the bird (Bramanti et al. 1988, Wilson et al. 1991, 1993, Benvenuti et al. 1998, Davis et al. 1999, Wilson 2001). Earlier versions of the compass in the system only worked accurately when close to horizontal (Bramanti et al. 1988, Wilson et al. 1993) so that they were subject to considerable error in animals that dived steeply. This problem has been eliminated by development of a fully 3-dimensional compass (Davis et al. 1999, Hochscheid \& Wilson 1999). Although this method gives finely resolved relative spatial movement over a time scale of a few seconds (Wilson 2001), it is subject to drift such that absolute errors in position can be substantial, with these errors tending to increase as a function of total device deployment time. This drift is primarily incurred due to wind and currents which may move the bird even though the speed sensor, which detects motion relative to that of the environment, indicates otherwise. The magnitude of drift problems can be alluded to by comparing the calculated end point of a foraging trip with the known end point (Bramanti et al. 1988). Appropriate software can then be used to overlay the known start and end points to accord with their true geographic co-ordinates and then to correct all other positions to accord (Fig. 1). During 63 foraging trips of 49 individual Pygoscelis penguins breeding at Ardley Island, Antarctica, determined by dead reckoning, where start and finish positions of the birds were known, the mean error in the calculated end position relative to its actual position was $1.2 \mathrm{~km}(\mathrm{SD}=1.8)$ for trips with a mean foraging range of $6.7 \mathrm{~km}(\mathrm{SD}=8.0)$ and a mean total travelled distance of $18.9 \mathrm{~km}$ ( $\mathrm{SD}=17.5$ ) (Wilson 2001). Superimposition of the correct end position on the projected end position will tend to lead to maximum errors of approximately half the given mean (ca. $0.6 \mathrm{~km}$ ) at the half-way point of the calculated route, with errors tending to diminish towards the start and end of the foraging trip. It should be noted that the error due to drift in dead reckoning systems is primarily a function of time, rather than distance travelled because the animal is subject to drift even when it is not being propelled by its own means. The absolute amount of drift 
depends on behaviour, e.g. flying, resting on the water, etc. The viability of dead reckoning over a time scale of days has yet to be tested, and its utility will depend greatly on the current/wind conditions at the time. It is perhaps worth noting that in a technically perfect dead reckoning system, errors in positional calculations could be used to infer ambient current conditions. The overall utility of dead reckoning would be greatly enhanced by combining it with some other, independent measure of position, such as via GPS so that absolute, infrequent satellite-determined fixes could be used to correct for drift-incurred errors in the dead reckoning system (Wilson 2001).

Global Positioning System. GPS receivers have been used successfully on some marine mammals (e.g. Sisak 1998) and for short periods on homing pigeons (von Hünerbein et al. 2000). This system has been deployed on seabirds for the first time over the last few months (Fig. 2). As with PTTs, this technology cannot be used underwater, but, since there are 24 relevant satellites orbiting the earth, a fix can be acquired at any time the animal is at the surface. The time needed for a positional fix varies between $30 \mathrm{~s}$ and 15 min depending on the accuracy of information on the animal's position already stored in the unit although a continuously functioning GPS can update position once every $1 \mathrm{~s}$ or so (Kaplan 1996). Immediately prior to the year 2000, GPS had an accuracy which was long term, consistently better than all systems considered above, being approximately $100 \mathrm{~m}$ for normal GPS and $<10 \mathrm{~m}$ for differentially corrected GPS (Kaplan 1996). On 1 May 2000, the US Department of Defence discontinued the selective availability (S/A) policy which deliberately degraded the accuracy of GPS. This improves the receiver accuracy by a factor of about 10 so that errors can be expected to be within ca. $5 \mathrm{~m}$ for $95 \%$ of the fixes (von Hünerbein et al. 2000). Although data loggers for GPS are currently too large to be used on most seabirds, projected size reduction makes it likely that they will be applicable to a fairly wide spectrum of species in the near future. The accuracy of the system and the large number of positional fixes means that the use of GPS technology is likely to revolutionise our understanding of seabird movements at sea and their potential use as a monitor of the marine environment.

In summary, the above systems all give information on geographic position with a variety of different accuracies. With the exception of GPS, all accuracies ascertained by fixed location trials appear to decrease when the units are placed on free-living animals due to movement, diving, etc. Determination of these errors is problematic since there is no system for ground truthing acquired data, although certain, fortuitous, events, such as the presence of albatrosses far inland, may give certain minimum error estimates. Similarly,

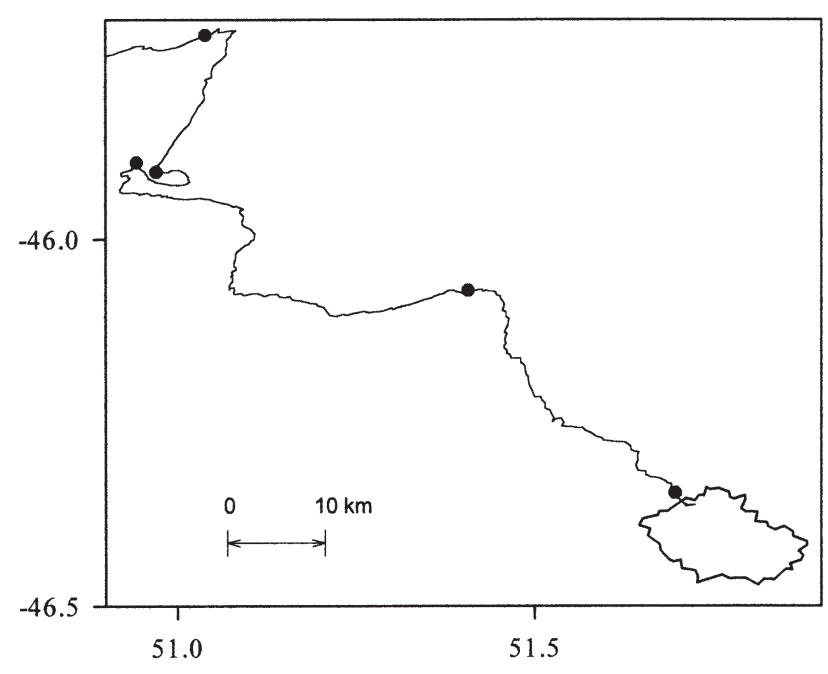

Fig. 2. First $8 \mathrm{~h}$ of movement of a wandering albatross Diameda exulans leaving Possession Island, Crozet Islands, as estimated by a miniature GPS. Dots indicate where the bird alighted on the water (Weimerskirch, Bonnadona, Mabille, Bailleul \& Lipp unpubl. data)

equipment of animals simultaneously with 2 systems makes it difficult to ascribe inconsistencies in the positions completely to either one system or the other, although errors are usually ascribed to the system considered to be less accurate. This will change when miniaturised GPS systems can be deployed on seabirds, but until that time we will have to make do with rather imprecise values for positional errors. The rate at which fixes can be provided is critically important when oceanographic variables are to be monitored virtually continuously. In this respect, even the most accurate system becomes correspondingly less useful as the frequency with which positional fixes can be determined decreases because the projected position of the bird has to be interpolated between points. An ideal compromise is perhaps a combination of systems such as dead reckoning together with PTTs or GPS, as suggested above. Ultimately, however, the system to be used for positional information must be decided by the questions being asked in the study.

\section{Depth}

The accurate determination of the depths exploited by seabirds is also highly relevant if the 3-dimensional position of the variable to be measured is to be quantified. Three elements are important in this regard: the accuracy of the pressure transducer, the resolution of the recording system and the correctness of the temperature compensation within the measuring unit. The ability of the sensor to measure changes in 
ambient pressure correctly depends primarily on the size of the pressure-sensitive surface, the larger units generally being more accurate. This is unfortunate because smaller units are clearly more desirable for deployment on seabirds. Systems available today generally vary in resolution between 8 and 16 bits (see above), giving 255 and 65535 measurement steps respectively over the sensor's specified range. Obviously, 16 bit resolution makes determination of utilised depths much more accurate, assuming the pressure transducer is good enough, because the resolution in depth is given by the maximum depth range divided by the number of measurement steps (Fig. 3). However, even the best pressure transducers resolved to 16 bit cannot give accurate information unless they are carefully calibrated and compensated for temperature effects. Seabirds spend much time at the water/air interface, and thus associated loggers are subject to radical changes in temperature. For example, a black, back-mounted logger on Magellanic penguins may experience temperatures of between 7 and $35^{\circ} \mathrm{C}$ over relatively short periods due to the difference in temperature between the water and the insolation experienced by the unit when the penguin is at the surface. An uncorrected output from a pressure transducer may vary by $3 \%$ for any specific pressure under this temperature regime. Thus, a unit with a full-scale measurement of $200 \mathrm{~m}$ may give up to a $6 \mathrm{~m}$ error in depth estimates at any position in the water column (or at the surface) if the pressure transducer is not temperature corrected. Due to heat flow within the logger, it is

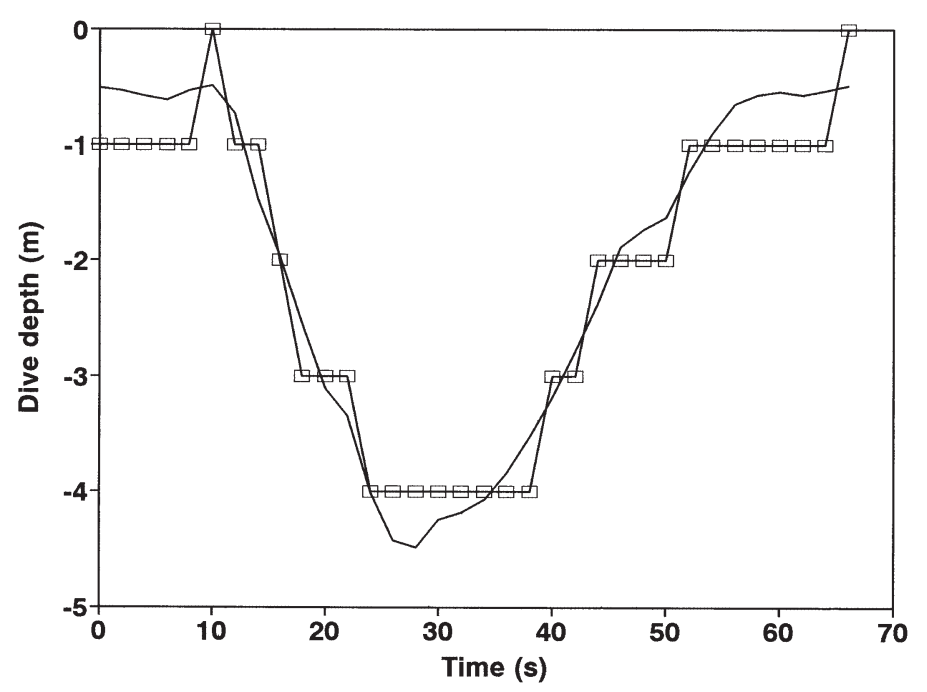

Fig. 3. Example of depth utilisation by a Magellanic penguin Spheniscus magellanicus during a single dive using 8 bit (lines with squares) and 16 bit resolution (simple lines). The pressure transducer had a maximum measurement range of $200 \mathrm{~m}$ therefore of critical importance that the temperature sensor to be used for correction purposes be subject to a regime as closely mirroring that of the pressure transducer as possible. While this is relatively easy, it is at odds with rapid measurement of environmental temperature (see below).

\section{Quality of the environmental data collected}

There are a number of sensors available which can be used to measure a variety of environmental variables, both biotic (e.g. quantities of prey ingested: Wilson et al. 1992b, 1995a, Charrassin et al. 2000), for catch per unit effort statistics and hence prey densities (e.g. Wilson et al. 1993, Grémillet 1997, Garthe et al. 1999), and abiotic (e.g. salinity: Sturlaugsson \& Johannsson 1996). Oceanographers and marine ecosystem researchers are interested in examining a number of major variables, these being temperature, density, salinity, light extinction, oxygen, dissolved organic carbon, dissolved organic nitrogen, dissolved organic phosphorus and chlorophyll a (e.g. Birot et al. 1998, Longhurst 1998). Topics requiring such data cover a vast scope of areas from analysis of small-scale plankton blooms to global circulation models, including El Niño and global climate change. To date, however, we know of only 2 variables that have been monitored by use of seabirds, these being temperature and light, and it is to these that we will restrict ourselves in order to illustrate the general principles and pitfalls which need to be considered.

\section{Temperature}

Measurement of sea temperature is considered of major importance for marine environmental monitoring. Classically it is performed by ship-borne CTD casts which give vertical temperature profiles of selected stations (e.g. Pond \& Pickard 1983).

Almost all loggers currently used on seabirds have the capacity to measure ambient temperature. However, the original function of this is derived from temperature compensation of other transducers in the unit so that the emplacement of the temperature sensor is, or should be, linked to the position of these sensors (see above). To what extent do temperature sensors so placed lend themselves to reliable measurement of ambient temperature, given the highly mobile nature of seabirds and their tendency to expose themselves to a widely ranging temperature regime? There are 2 situations to be considered here: measurement of SST and measurement of temperature as a function of depth. 
Sea surface temperature. The first situation is best exemplified by volant species, with leg-mounted loggers, which travel above the water's surface before alighting for some period before taking off again. During flight the temperature recorded by the logger is generally fairly high, on the order of $25^{\circ} \mathrm{C}$, since the unit is often tucked up in the feathers. At the moment the bird alights and extends its feet into the water column the measured temperature drops precipitously (Fig. 4a), with the rate of change of temperature being, in some way, proportional to the difference between measured and actual temperature (Fig. 4b). Thus, although loggers measuring temperature may readily indicate when birds have alighted on the water, considerable time may elapse before the measured temperature has dropped to that of the surface. If the time period necessary for the temperature sensor of the logger to stabilise does not occur before the bird takes flight again, then the SST cannot be accurately measured. To put the qualities of existing loggers into perspective, we considered the rate of change of measured temperature from various loggers in waterbaths simulating a bird landing on the sea surface. There were substantial differences between the various logger types (Table 3), with the rate of change of temperature being dependent on the proximity of the sensor to the water on all sides. Units with superficially embedded temperature sensors on 1 side initially reacted quickly to the change in ambient temperature (cf. Wildlife Computers in Table 3); however, a substantial mass of embedding resin on the other side of the sensor slowed the rate of change of measured temperature radically following this initial rapid drop so that the time necessary for the units to reach base levels was considerably longer than other units where the mean overall distance between sensor and water was less (Table 3). It is notable that no single unit reached true base levels (or $99 \%$ thereof) before $62 \mathrm{~s}$, and that some units did not stabilise temperatures until $564 \mathrm{~s}$ (Table 3). These represent miminum time periods that birds must spend on the water before the SST measurement can be effected. This necessary time period might be somewhat shortened by deriving a general curve fit for measured temperature against time but such a process will be less precise and, in any event, necessitates a high sampling frequency which is not always practical.

The reactivity of the sensor need not be a problem provided that the equipped bird spends an appreciable amount of time on the water. It would appear, however, that at least some species of seabirds alight on the
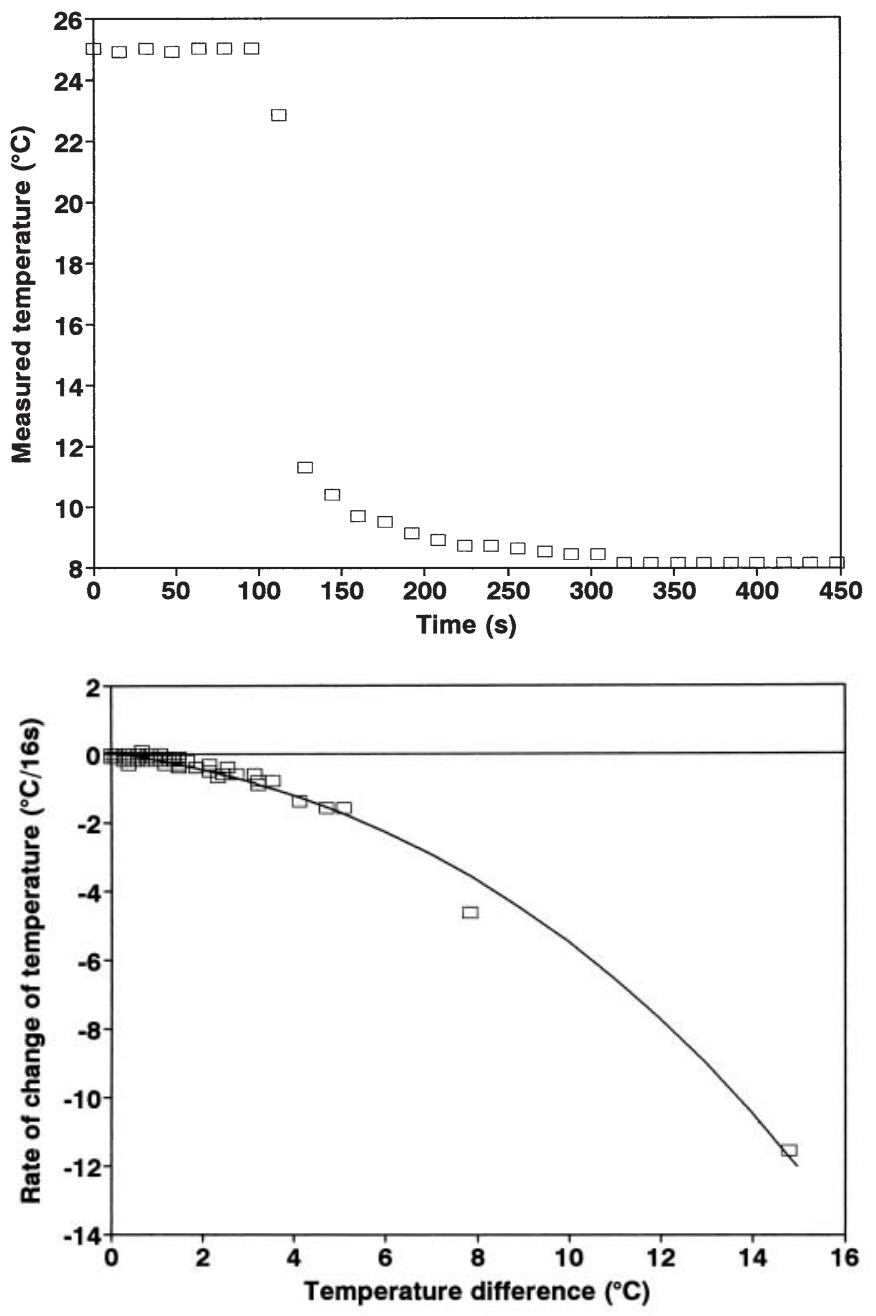

Fig. 4. (a) Example of the temperature measured by a legmounted LTD 100 on a northern fulmar Fulmarus glacialis, at the moment the bird alighted on the water. The unit was set to record data once every $16 \mathrm{~s}$. (b) Rate of change of recorded temperature as a function of the difference between the recorded temperature and that of the water for the same bird over a series of events during which the bird alighted on the water $\left(\right.$ at $8^{\circ} \mathrm{C}$ ). The curve fit takes the form $\mathrm{d} T / \mathrm{d} t=$ $\left(0.6-0.001 \Delta T^{3}\right)\left(r^{2}=0.99\right)$.

Table 3. Reaction speed of various logger types (for details see Table 2) to changes in environmental temperature. All units were immediately transferred from a $25^{\circ} \mathrm{C}$ waterbath to a $10^{\circ} \mathrm{C}$ waterbath

\begin{tabular}{|lcrrrrr|}
\hline $\begin{array}{l}\text { Time (s) } \\
\text { to reach: }\end{array}$ & DK 600 & LTD 100 & MkV & MkV $^{\mathrm{a}}$ & Mk VI & Onset \\
\hline $50 \%$ & 15 & 22 & 12 & 10 & 18 & 26 \\
$75 \%$ & 18 & 44 & 66 & 32 & 94 & 48 \\
$90 \%$ & 26 & 88 & 208 & 90 & 252 & 130 \\
$95 \%$ & 44 & 122 & 378 & 150 & 426 & 190 \\
$99 \%$ & 62 & 212 & 564 & - & 536 & 253 \\
a Unit with 1 & side of the temperature sensor exposed to water \\
\hline
\end{tabular}



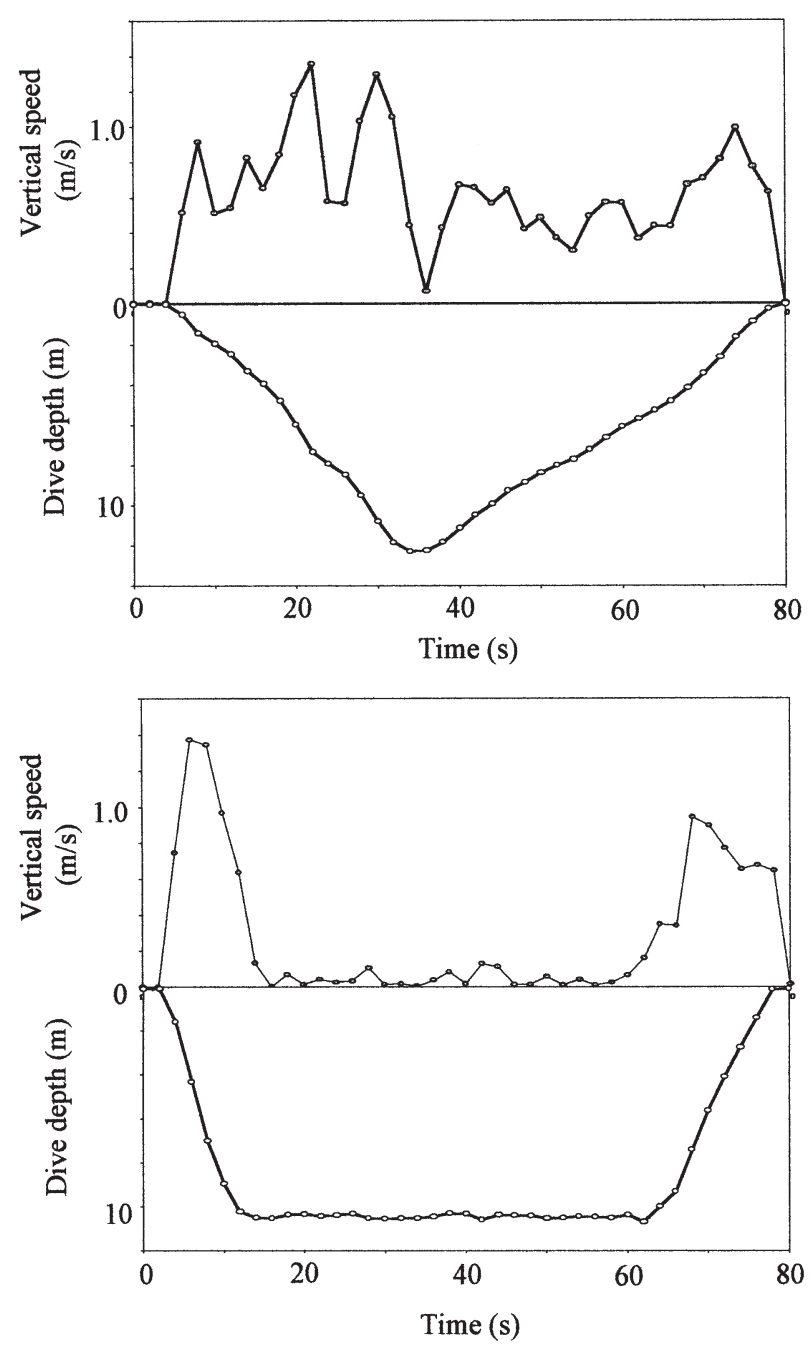

Fig. 5. Types of dive profile exhibited by Magellanic penguins (Spheniscus magellanicus) and associated rates of movement through the water column: V-dive (upper panel), U-dive (lower panel)

surface for just short periods. In $>5 \%$ of the cases in which black-browed albatross Diomedea melanophris equipped with foot temperature loggers settle on the water, they do so for $<4 \mathrm{~min}$, in $10 \%$ of the cases this time is $<6 \mathrm{~min}, 50 \%<29 \mathrm{~min}, 90 \%<308 \mathrm{~min}$ (Grémillet et al. 2000). Comparable values for the Northern Gannet Sula bassanus were: $10 \%<5 \mathrm{~min}, 50 \%<18 \mathrm{~min}$, $90 \%<88 \min$ ( $\mathrm{n}=75 ; 3$ birds) (S.G. unpubl. data).

Depth-dependent temperature measurements. Sensor reactivity becomes problematic when attempts are made to use loggers to measure temperature as a function of depth. Seabirds have dive patterns that generally conform to 1 of 2 major types which have been classified as V-shaped (Fig. 5) or U-shaped (Fig. 5) (Wilson et al. 1996, see also Schreer \& Testa 1996). Rates of change of depth during the descent and ascent phases are depth-dependent, being higher for dives terminating at deeper depths; rates are typically between 0.7 and $1.9 \mathrm{~m} \mathrm{~s}^{-1}$ for cormorants (Wilson \& Wilson 1988, Croxall et al 1991, Wanless et al. 1993, Watanuki et al. 1996, Grémillet et al. 1998), around $0.9 \mathrm{~m} \mathrm{~s}^{-1}$ for auks (Croll et al. 1992, Clowater \& Burger 1994) and between 0.7 and $2.2 \mathrm{~m} \mathrm{~s}^{-1}$ for penguins (Kooyman \& Kooyman 1995, Wilson et al. 1996, Peters et al. 1998, Pütz et al. 1998, Wilson \& Peters 1999). This means that birds typically spend $<1.5 \mathrm{~s}$ per vertical metre depth in the water column. Thus, slowly responding temperature sensors within loggers (Table 3) will never equilibrate to any particular temperature down the water column which leads to recorded changes in temperature due to changes in depth being out of synchrony with actual changes in depth so that the regression of temperature against depth results in an ambiguous relationship (Fig. 6a). Simplistically, one could attempt to determine the form of temperature against depth by taking means of equivalent points from the descending and ascending parts of the dive profile, but in practise this is not correct.

What properties should a temperature sensor have if it is to be used to measure water temperature as a function of depth in a diving seabird? We consider that $T_{0}$ is the initial temperature at time $t=0, T_{1}$ is the temperature that the sensor has to reach, being $T$ at infinite time, and that $t_{99}$ is the time the sensor needs to adjust to $99 \%$ of the temperature change $T_{1}-T_{0}$. Our general assumption is that the rate of change of temperature takes the form:

$$
\mathrm{d} T / \mathrm{d} t=\mu\left(T_{1}-T_{(t)}\right)
$$

where $\mu$ is a constant. Thus:

$$
T_{t}=T_{1}-\left(T_{1}-T_{0}\right) \mathrm{e}^{-\mu t}
$$

and the sensor reaches $99 \%$ of $\left(T_{1}-T_{0}\right)$ if $\mathrm{e}^{-\mu t}=0.99$, that is:

$$
t_{99} \leq 1 /(\beta D+\alpha) \quad \text { or } \quad t_{99} \approx 0.01 / \mu
$$

where $\alpha$ and $\beta$ are both constants. If the rate of descent $V_{\mathrm{v}}=\beta D+\alpha$ (Wilson 1995), where $D$ is depth, then the time spent per unit depth in the water column is given by:

$$
\text { Time }=1 / V_{\mathrm{v}}=1 /(\beta D+\alpha)
$$

Thus, for the sensor to measure temperature effectively in a diving bird:

$$
-\ln (0.99) / \mu \leq 1 /(\beta D+\alpha)
$$

where we consider that effective measurement means that the sensor must react within a metre travelled vertically and that $V_{\mathrm{v}}$ is measured in $\mathrm{m} \mathrm{s}^{-1}$.

Consideration of the reaction speed of various temperature sensors (Table 3) indicates that not one of the units currently on the market will enable researchers 
to derive temperature against depth easily for the rate at which seabirds tend to move through the water column during the descent phases of the dive. Furthermore, few seabirds spend such extended periods during the bottom phases of dives that the $t_{99}$ for the logger can be reached and, even where this is the case (e.g. compare Emperor and King penguins; Kooyman et al. 1992, Robertson 1995, Pütz et al. 1998) only 1 data point can be acquired per dive for each locality.

The solution to the problem is to incorporate a second temperature sensor into the logging unit which is not used to compensate other transducers (Fig. 6b,c). This sensor can be placed to project away from the body of the logger and minimally surrounded by any material with thermal inertia. Examination of some of the commercially available sensors indicates that some achieve $t_{99}$ within a fraction of a second and would be well suited for this purpose. Wildlife Computers (USA) already market a logger (Mk VII) which has a temperature sensor on the end of a stalk, the principal application for this being deployment on fish. The manufacturer's specifications are that when this stalk is $100 \mathrm{~mm}$ long, the time taken for the unit to register a $63.3 \%$ change is $2.8 \mathrm{~s}$, although whether such a stalk can safely project from a seabird's leg is another consideration.

\section{Light}

Quantification of the optical properties of oceans is also fundamental in any comprehensive oceanographic programme since light is a prerequisite of photosynthesis (e.g. Tyler 1977). Instrumentation ranges from classical in situ Secchi disk measurements (Tyler 1968) to remotely performed spectral analyses (e.g. Spinrad et al. 1994).

Diving birds can very easily be used to measure changes in light as they move up and down the water column (e.g. Wanless et al. 1999), and such measurements do not incur the lag problems of the type discussed above for temperature (Fig. 6a,b). The sensor itself is typically a photo-diode or photo-voltaic cell which is assessed by the logging unit over a period of a few milliseconds. Sensors generally measure over a wide range of wavelengths (Fig. 7a,b) (e.g. see the BPX sensor cited in Wanless et al. 1999, which measures
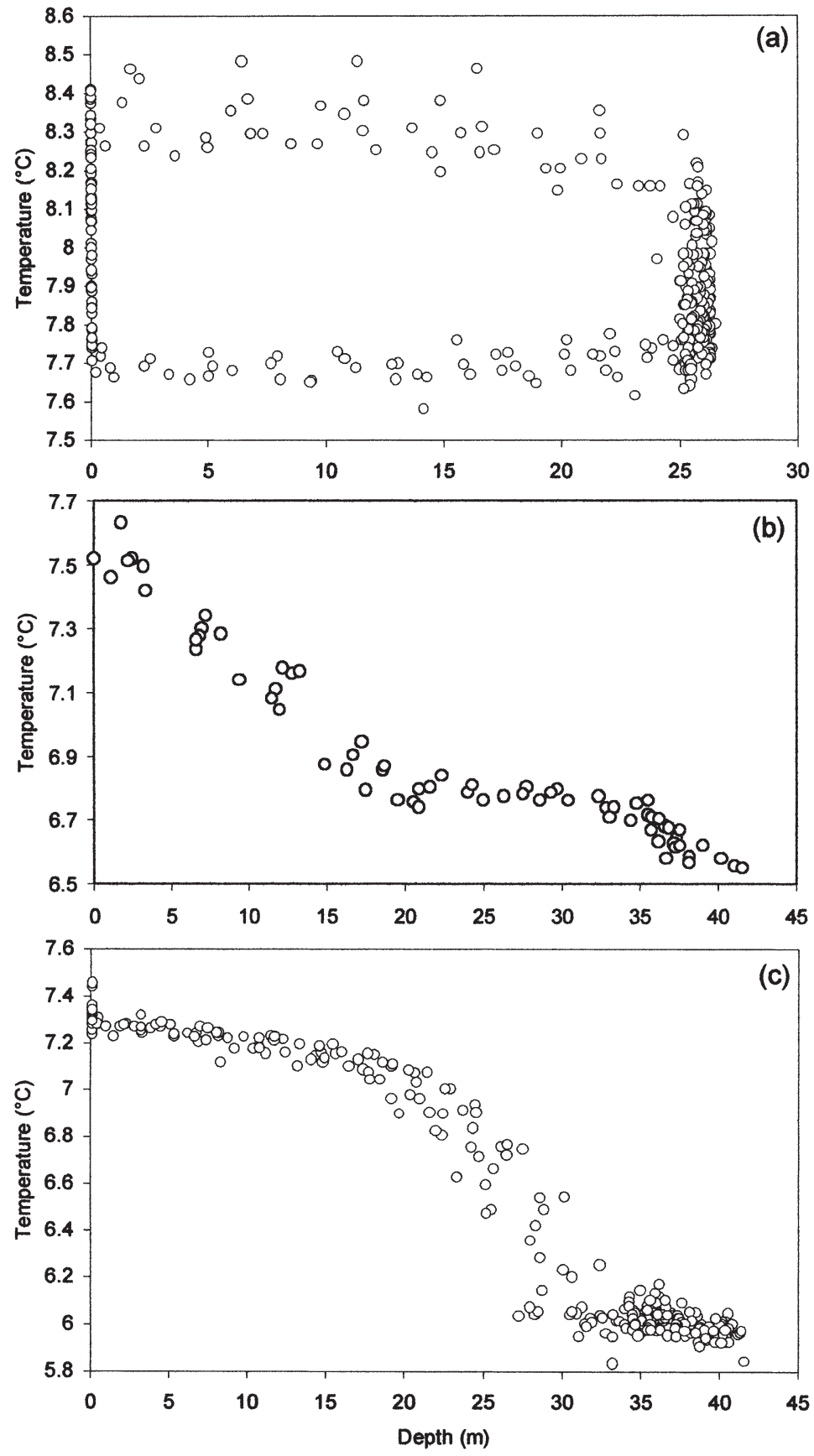

Fig. 6. (a) Dive depth and measured temperature taken from a sensor with large thermal inertia derived from a logger (DK 600) attached to the back of a Magellanic penguin Spheniscus magellanicus foraging near Cabo Virgenes, Argentina. Temperature decreased down the water column but the slow reactivity of the temperature sensor results in a noticeable lag in the temperature profile. (b) Measured temperature taken by a rapidly reacting sensor versus depth for 4 dives executed by a Magellanic penguin foraging near Cabo Virgenes, Argentina. The minimal lag in response results in a clear relationship between water temperature and depth. (c) Measured temperature taken by a rapidly reacting sensor versus depth for 4 dives executed by the same Magellanic penguin as depicted in (b) foraging near Cabo Virgenes, Argentina. Here, the bird was in a different body of water as indicated by the different temperature/depth profiles 
within the broad band of 350 to $1100 \mathrm{~nm}$ ) such that judicious use of filters over the sensor makes it possible to measure light extinction patterns of highly specific wavelengths within the full visual spectrum, according to requirements (Spinrad et al. 1994). Units measuring light can do so with varying degrees of resolution (up to 16 bit) within a variety of selected ranges. For example, the Wildlife Computers Mk V light sensor measures light in a range of at least $-1.3 \log _{10}$ to $3.8 \log _{10}$ lux (data in Wanless et al. 1999) and the DK logger units (Table 2) can measure light of intensities between $-2 \log _{10}$ and $3 \log _{10}$ lux in steps of ca. 0.03 lux and is easily sensitive enough to measure biolumines-
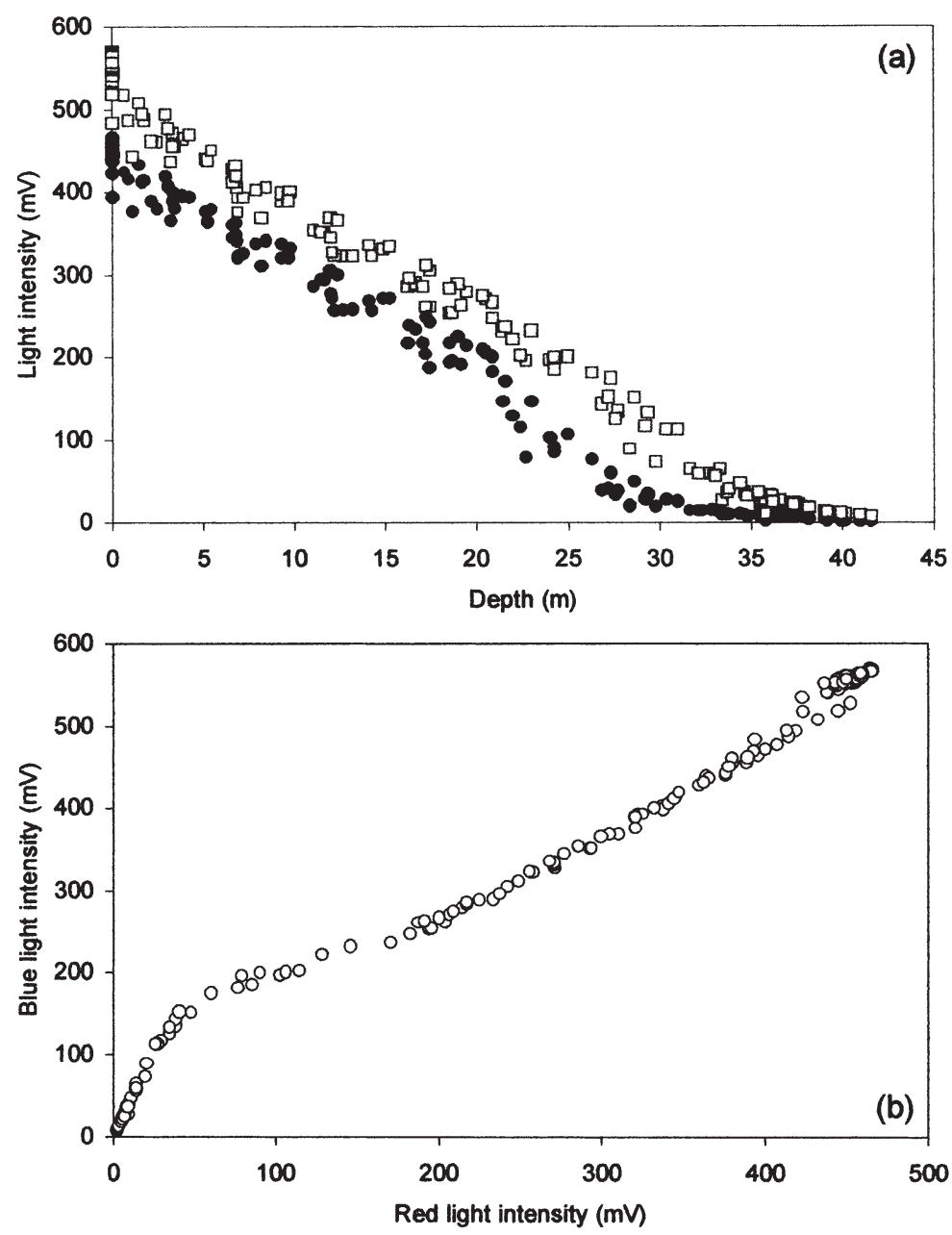

Fig. 7. (a) Dive depth and measured light intensity for blue (squares) and red (circles) light for 4 dives derived from a logger (DK 600) attached to the back of a Magellanic penguin Spheniscus magellanicus foraging near Cabo Virgenes, Argentina. Although there is no lag in response time of the sensor, scatter is noticeable in the shallower zones. This is due to variation in the orientation of the bird so that the light impinges at a highly variable angle on the sensor. In the deeper areas the bird will tend to be swimming approximately parallel to the water surface during the bottom phase of the dive. (b) Measured blue versus red light intensity for the 4 major dives depicted in (a) cence at night (manufacturers' specifications, R.W. unpubl. data). This compares favourably with conventional oceanography (Jerlov 1976, Spinrad et al. 1994).

However, measurement of light is not completely unproblematic. Birds descending in the water column do so at a variety of angles (e.g. Wilson 1995) such that the angle at which the light impinges on the sensor varies accordingly, producing a correspondingly variable output (Fig. 7a). The problem of light extinction is, in any event, complicated by sun angle which is a function of time of day, day of the year and geographic location, because the depth to which light will penetrate down the water column is dependent on the angle at which it impinges (Jerlov 1976). In order to appropriately address the above complexities of light extinction curves, 3 approaches are possible: (1) the sensor angle can be ignored and some measure of light extinction versus depth can be derived with inherent scatter (Wanless et al. 1999) (Fig. 7a); (2) the logging unit can contain a sensor to indicate when it is horizontal so that the angle at which the light impinges on the sensor can be held constant; and (3) a sensor could be built into the logging unit so that the exact angle of the sensor can be determined at any time and the recorded light values appropriately handled. The second case, although relatively easy to realise, gives relatively few data since most diving birds are only horizontal at the point of maximum depth. The third case necessitates some complex mechanism to determine bird angle with respect to gravity and to the ordinal compass system (see e.g. Davis et al. 1999). Apart from Davis and coworkers, a system of this type has been realised in a 3-dimensional, miniature ship's compass which has been described in its basic form by Hochscheid \& Wilson (1999) and which can be used underwater to determine animal orientation (Storch et al. in press, cf. Hochscheid et al. 1999). Details of the errors of the system have not been published yet, but laboratory work indicates that both orientation and dive angle can be resolved to better than $4^{\circ}$ (R.W. unpubl. data).

\section{Sampling regime effected by the birds}

Having detailed the technology for determination of bird position as well as measurement of abiotic marine variables it is appropriate to consider the way in which seabird foraging behaviour leads to a particular sam- 
pling regime of the environment. In this, it is important to remember that seabirds do not forage randomly, but process a variety of complex environmental inputs (e.g. Hutchinson et al. 1984, Nevitt et al. 1995) in order to make decisions about which areas to sample (Wilson \& Peters 1999). Thus, they do not exhibit specific orbits, as do satellites, nor do they move with currents, as do drifter buoys. The decision-making process regarding areas of perceived importance makes seabirds fundamentally different from all other sampling methodologies used to date. Indeed, their identification of prey aggregations (e.g. Cairns \& Schneider 1990, Hunt et al. 1990) gives a fortuitous bias so that environmental monitoring via seabird studies should be seen as particularly important.

\section{Space utilisation during the nesting season}

Birds with eggs or chicks are central place foragers (Orians \& Pearson 1979), having to return to their nest site periodically to attend to the constraints imposed by the brood. The length of the foraging trip and the travelling speed determine the theoretical maximum range that a breeding seabird might cover (e.g. Lishman 1985). However, in reality, deviations from a straight line course (Wilson 2001) coupled with highly variable activities at sea (Jouventin \& Weimerskirch 1990) makes calculation of area coverage using such measurements overly simplistic.

There are essentially 3 phases to foraging trips. Trips generally begin with a phase during which birds move rapidly and directly away from the nest site (e.g. Bethge et al. 1997, Gaston \& Jones 1998, Weimerskirch 1998a,b), a behaviour which allows them to minimise time in zones where prey density is low (Birt et al. 1987, Irons 1998). At some point the behaviour changes substantially when active search begins. In species such as auks or cormorants, where prey are located during dives made from the surface (Johnsgard 1993, Gaston \& Jones 1998), the birds alight on the water and begin diving. If prey densities are high enough the birds remain at this site. If not, they move elsewhere and begin the process again (Benvenuti et al. 1998, Falk et al. 1999, Grémillet et al. 1999). In other species, such as many albatrosses and penguins, which do not substantially alter travelling mode during foraging, the tracks become more meandering as birds invest time searching restricted areas more thoroughly (Jouventin et al. 1994, Wilson 1995, 2001, Weimerskirch et al. 1997, Weimerskirch 1998a). As in the case with auks and cormorants, when areas are found to be non-profitable, birds will rapidly move away to another area before tracks become more meandering again. In a final phase, seabirds return rapidly and directly to the nest, with little deviation from a straight line course (e.g. Jouventin et al. 1994, Bethge et al. 1997, Bost et al. 1997). A consequence of this behaviour is that foraging tracks of nesting individuals are remarkably similar, even across groups, although the scales may differ substantially. Jouventin et al. (1994) recognised 2 primary types of foraging tracks in King penguins, distinguished by their ellipticity: 'direct' trips, in which birds moved directly to one spot, foraged and then returned directly, and 'circular' trips, in which birds executed a looping course with several foraging stops. Similar patterns have been documented for many seabird species (Heath \& Randall 1989, Weimerskirch 1998a), although behaviour varies substantially both inter- and intraspecifically (e.g. Weimerskirch et al. 1993, Weimerskirch 1998a). This has profound implications with respect to the area covered by nesting birds and thus the utility of birds for monitoring the environment. Where birds move to a single foraging area, in doubling back on their tracks they essentially re-cover previously travelled ground, whereas any movement in elliptical courses increases the new distance covered, with the more circular routes giving the most disparate spatial data.

In projected environmental monitoring studies, the utility of seabirds for covering extensive areas of ocean is enhanced if there is considerable inter- and intraindividual variation in foraging areas. In fact, seabirds seem to show virtually all possible combinations of variability and invariability (e.g. Weimerskirch et al. 1993, Ostrand et al. 1998). There are, for example, species in which individuals apparently repeatedly return to the same site to forage, although the population forages over a fairly disparate area, e.g. great cormorants (Grémillet et al. 1998). In other species, such as the shy albatross around Tasmania, Australia, most individuals forage at a single, relatively restricted site (Brothers et al. 1998), while others, such as the wandering albatross, forage at highly variable localities (Weimerskirch 1998a). In addition, many Procellariiformes alter foraging locations according to body condition; they tend to alternate short trips, with restricted foraging ranges, with longer meandering trips (Weimerskirch 1998b). Although spatial variability in the species used is apparently an asset for environmental monitoring studies, species which may move over, or through, particular sites at intervals can be used to examine temporal trends in key variables.

\section{Speed of area coverage}

Although most birds should actually travel at fairly fixed speeds in order to minimise costs of transport (Pinshow et al. 1977, Culik et al. 1994, Hedenström \& 
Alerstam 1995), the perceived speed with which the birds move over, or through, the ocean is dependent on the interval over which the speed is measured, because the course taken becomes increasingly more direct as the measurement interval decreases (e.g. Hull et al. 1997, Wilson 2001). However, even over a period of some hours, seabirds can cover astonishing distances. King penguins have been recorded as travelling at minimum mean speeds of $13 \mathrm{~km} \mathrm{~h}^{-1}$ over $6 \mathrm{~h}$ or $8.5 \mathrm{~km} \mathrm{~h}^{-1}$ over $11 \mathrm{~h}$ (data obtained from fixes obtained using satellite telemetry; C.-A.B. unpubl. data). Among the volant seabirds, where travelling speeds are considerably higher, wandering albatross can travel over $1200 \mathrm{~km}$ in $<20 \mathrm{~h}$ (data from PTTs; Weimerskirch et al. 1993), a mean travelling speed of $60 \mathrm{~km} \mathrm{~h}^{-1}$. Even smaller species are capable of rapid, long-distance travel. For example, a white-chinned petrel has been documented as having travelled from South Africa to the Crozet Archipelago, southern Indian Ocean, and back, a round trip of $3068 \mathrm{~km}$, at an average speed of $52.7 \mathrm{~km} \mathrm{~h}^{-1}$ (Catard \& Weimerskirch 1999).

Although the distance covered per unit time gives a measure of the utility of various seabird species for studying environmental variables over different scales of time and space, it is ultimately the specific area usage that is of primary interest. The likelihood that this area will be large or distant from the breeding site is dependent on a number of factors: the length of the foraging trip, the travelling speed of the bird and the economy of the energetics of the movement of the bird in question (Pennycuick 1997). The area covered by foraging seabirds lies between the ranges of terns and some gulls, which generally forage within a few kilometres of the breeding site (Pearson 1968, Becker et al. 1993, Garthe 1997) as is also often the case with penguins (Wilson 1995), to those of the Procellariiformes, which may regularly range many hundreds of kilometres (Weimerskirch 1998b). The most consistent long-distance round-trip of $3500 \mathrm{~km}$ is made by whitechinned petrels commuting from the Crozet Archipelago to South Africa during incubation (Weimerskirch et al. 1999).

\section{Space utilisation during the non-breeding season}

During the non-breeding season, seabirds are not constrained to return to their nesting sites and can thus potentially range much further than they can during breeding. There are, however, few studies that can verify this due to the difficulties inherent in equipping seabirds for long periods (e.g. Wilson et al. 1998a, Prince et al. 1998). Data from penguins show that overwintering Adélie penguins may travel at least $1470 \mathrm{~km}$ from the colonies (PTT data from Davis et al. 1996), chinstrap penguins $1600 \mathrm{~km}$ (GLS data from Wilson et al. 1998b) while even Antarctic gentoo penguins, considered to be sedentary (Croxall \& Davis 1999), range further than during the breeding season by a factor of 2 (Wilson et al. 1998a). To our knowledge, the only comparable data on area utilisation currently available for Procellariiformes were derived from 2 albatross species. Black-browed albatross equipped at New Island, Falklands, spend significantly less time flying per day than they do during the breeding season (37 and $52 \%$ of their total time, respectively; Grémillet et al. 2000), and have a mean bird-colony distance of $680 \mathrm{~km}$ (Grémillet et al. 2000). Interestingly, these birds apparently use the same rough geographic areas during both the breeding and the nonbreeding season (Grémillet et al. 2000). A recent study on 4 wandering albatross showed that at least 1 bird ranged much further during the non-breeding season than it would have during the breeding season (Weimerskirch \& Wilson 2000). This ties in well with what is believed normal for most Procellariiformes, since there are well-documented cases of birds exploiting completely different areas during the breeding and non-breeding seasons (del Hoyo et al. 1992 and references therein).

Overall, area coverage by non-breeding seabirds is remarkably global, with birds ranging many thousands of kilometres into remote oceanic areas. This can be illustrated by consideration of a single species breeding in the southern oceans, the wandering albatross. This species breeds at just 8 island sites, but the non-breeding range extends from the edge of ice areas almost up to the equator in all of the world's major oceans (Fig. 8). Clearly, their potential for remotely monitoring large tracts of ocean with difficult access is great although the time that this species spends in areas that are not of specific interest may partly negate the collection of useful data for the oceanographer.

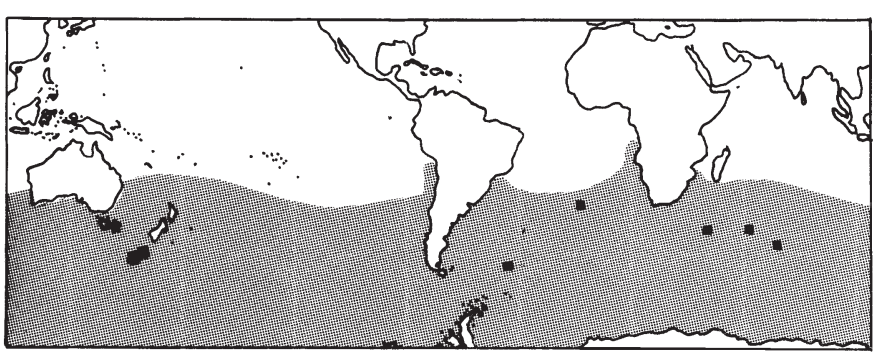

Fig. 8. Map showing (匹) the only known breeding sites of the wandering albatross in relation to the oceanic areas (in grey) exploited by these birds (data from del Hoyo et al. 1992) 


\section{Behavioural and morphological considerations for effective measurement of environmental variables}

\section{Recovery of recording units}

The systems presented here for measuring marine environmental variables all record, rather than transmit, data. As such, the devices have to be recovered in order to access data. This means that access to the carrier has to be guaranteed subsequent to a period at sea. The likelihood of device recovery varies considerably, being highly species- and locality-specific, as well as possibly being dependent on the wearing time of the units. Difficulties in device recovery may be due to device-induced changes in nest absence patterns (e.g. Watanuki et al. 1992) or to nest or site desertion (e.g. Hatch et al. 2000). Nest desertion and site infidelity occur even in non-equipped seabirds (e.g. Gaston \& Nettleship 1981), but manipulated animals may be even more intractable (cf. Wanless et al. 1985), although specific data are often difficult to extract from the literature. In a study during which we equipped 53 Magellanic penguins breeding at 6 sites in the southern Atlantic with logging units, we recovered 49 devices $(92.5 \%)$ after a ca. 6 wk wearing period (R.W. unpubl. data). Hatch et al. (2000), however, caused massive (but unspecified) nest desertion in auks fitted with PTTs in a study in Alaska! Clearly, the percentage recovery of deployed units will be a major determinant in the viability and moral acceptability of studies of this type (see below).

Contact with the water

In order to ensure effective measurement of environmental variables, equipped seabirds have to have contact with the water, and the most widely ranging species are of little use if this occurs infrequently. The continued miniaturisation of electronics means that loggers can now be attached to the legs of some seabird species such as albatrosses (Wilson et al. 1995c), so that birds only have to alight on the water to effect measurement (Weimerskirch et al. 1995). Few studies have considered how often seabirds alight on the water. However, breeding black-browed albatross alight on the water a mean of once every $111 \mathrm{~min}$, or 13 times $\mathrm{d}^{-1}$ (Grémillet et al. 2000). Wandering albatross alight once every 53 min (SD = 12) (Weimerskirch et al. 1997) such that, if it is assumed that these birds travel at speeds on the order of $15 \mathrm{~m} \mathrm{~s}^{-1}$ (Pennycuick 1982), they would be sampling the water once every $48 \mathrm{~km}$ travelled. In other studies, stomach temperature analysis indicates that equipped birds catch prey on average once every 3.6 to $4.4 \mathrm{~h}$ but alight on the water once every $1.1 \mathrm{~h}$ (Weimerskirch \& Wilson 1992, Weimerskirch et al. 1994, 1997). This suggests that prey is caught once every ca. 4 landings, indicating that not all landing events need be directly associated with acquisition of prey, i.e. prey distribution does not define the positions that seabirds might choose to alight and thus potentially sample the water. Limited analysis of data from northern gannets Sula bassana indicate that these birds alight once every $32 \min (\mathrm{SD}=42.9, \mathrm{n}=9 \mathrm{~d}$, 3 birds) (S.G. unpubl. data).

\section{Depth-dependent profiles}

For environmental variables to be measured down the water column, the equipped birds have to dive. Ashmole (1971) classified seabirds according to their foraging habits as pursuit divers, plunge divers, surface feeders and flight feeders. Neither flight nor surface feeders are of any use for measuring depthdependent variables. Plunge divers (Table 4) are of restricted use because they plunge into the water at a high speed from the air, traversing the upper layers extremely fast, but coming rapidly to a halt in a rather shallow dive (e.g. cape gannet Sula capensis: mean dive depth 5.9 m, maximum $12.6 \mathrm{~m}$; Adams \& Walter 1993, cf. Le Corre 1997) during which time they have been underwater for relatively short periods (e.g. Schreiber et al. 1975, Duffy 1983, Garthe et al. 1999, 2000). This leaves little room for time-based sensor equilibration and, in any event, necessitates that the logger measure at extremely short intervals. A surprising number of seabirds habitually dive to find food although only 4 groups regularly reach depths in excess of $20 \mathrm{~m}$, these being the shearwaters, auks, cormorants and penguins. There are records of the last 3 groups exceeding $100 \mathrm{~m}$ (Croxall et al. 1991, Croll et al. 1992, Wilson 1995), and Emperor penguins even dive in excess of $500 \mathrm{~m}$ (Kooyman \& Kooyman 1995). The amount of time that divers actually spend underwater and, therefore, are available to measure environmental variables is dependent on group. For example, penguins may be below the surface for up to $90 \%$ of the time at sea (Wilson \& Wilson 1990), while great cormorants spend ca. $20 \%$ of their time at sea underwater (Grémillet 1997).

\section{Bird size}

The extent to which it is practicable and acceptable to put devices on seabirds depends on the sizes of both. Nominally, researchers work according to the $5 \%$ rule, whereby the mass of the device should not exceed $5 \%$ that of the bird (for discussion of this and other aspects 
Table 4. Characteristics of the major seabird groups with regard to their applicability for monitoring marine environmental variables. Feeding method follows Ashmole (1971): 1, surface feeders; 2, plunge divers; 3, pursuit divers. The foraging range is taken to be the maximum likely during the breeding season. Data from multiple sources including Brown et al. (1978), Skira (1979), Burger \& Simpson (1986), Harper (1987), Barrett \& Furness (1990), Burger (1990), Burger \& Powell (1990), Prince \& Jones (1992), del Hoyo et al. (1992, 1996), Croll et al. (1992), Johnsgard (1993), Burger et al. (1994), Chastel (1994), Huin (1994), Oka (1994), Prince et al. (1994), Camphuysen (1995), Wilson (1995), Gaston \& Jones (1998), Ostrand et al. (1998), Ryan \& Nel (1998), Pütz et al. $(1998,1999)$ and R.W. unpubl. data

\begin{tabular}{|c|c|c|c|c|c|c|}
\hline $\begin{array}{l}\text { Common name } \\
\text { Family }\end{array}$ & $\begin{array}{l}\text { No. of } \\
\text { species }\end{array}$ & $\begin{array}{l}\text { Body } \\
\text { size } \\
(\mathrm{cm})\end{array}$ & $\begin{array}{l}\text { Principal } \\
\text { feeding } \\
\text { method }\end{array}$ & $\begin{array}{l}\text { Foraging } \\
\text { depths } \\
\text { (m) }\end{array}$ & $\begin{array}{c}\text { Foraging } \\
\text { range } \\
(\mathrm{km})\end{array}$ & $\begin{array}{c}\text { Length of } \\
\text { breeding } \\
\text { period }(d)^{\mathrm{a}}\end{array}$ \\
\hline $\begin{array}{l}\text { Albatrosses } \\
\text { Diomedeidae }\end{array}$ & 14 & $71-115$ & 1 & $0-13$ & $20-3800$ & $205-356$ \\
\hline $\begin{array}{l}\text { Auks } \\
\text { Alcidae }\end{array}$ & 22 & $15-46$ & 3 & $30-180$ & $1-150$ & $29-128$ \\
\hline $\begin{array}{l}\text { Cormorants } \\
\text { Phalacrocoracidae }\end{array}$ & 27 & $65-100$ & 3 & $10-130$ & $5-100$ & $58-100$ \\
\hline $\begin{array}{l}\text { Diving petrels } \\
\text { Pelecanoididae }\end{array}$ & 4 & $19-22$ & 3 & $30-80$ & $5-350$ & $87-112$ \\
\hline $\begin{array}{l}\text { Gannets/boobies } \\
\text { Sulidae }\end{array}$ & 9 & $69-93$ & 3 & $2-25$ & $5-400$ & $134-232$ \\
\hline $\begin{array}{l}\text { Gulls } \\
\text { Laridae }\end{array}$ & 46 & $27-71$ & 1 & $0-1$ & $1-70$ & $44-100$ \\
\hline $\begin{array}{l}\text { Pelicans } \\
\text { Pelecanidae }\end{array}$ & 7 & $114-170$ & 1,3 & $0-5$ & $1-150$ & $89-150$ \\
\hline $\begin{array}{l}\text { Penguins } \\
\text { Spheniscidae }\end{array}$ & 16 & $42-112$ & 3 & $30-500$ & $5-2000$ & $83-446$ \\
\hline $\begin{array}{l}\text { Petrels/shearwaters } \\
\text { Procellariidae }\end{array}$ & 85 & $14-87$ & $1,2,3$ & $0-70$ & $15-3600$ & $82-205$ \\
\hline $\begin{array}{l}\text { Terns } \\
\text { Sternidae }\end{array}$ & 40 & $23-53$ & 3 & $1-2$ & $1-200$ & $34-97$ \\
\hline
\end{tabular}

of bird equipment see Calvo \& Furness 1992); however, even quite small devices may affect seabird foraging ecology, especially in diving species in which hydrodynamic concerns become important (e.g. Wilson \& Culik 1992, Hull 1997). Seabirds vary in size from about $25 \mathrm{~g}$ for a storm petrel Hydrobatidae to $36 \mathrm{~kg}$ for an emperor penguin (Table 4). While the larger species are likely to be least affected by device attachment, no seabird is globally distributed so the species to be used will depend on the area under consideration and bird distributional data as well as size.

There is an important moral issue to be addressed when using seabirds to monitor the marine environment. To what extent can deleterious effects on the carrier animal be considered acceptable? There are 3 well-defined views on this question. One is that the well-being of the animal is irrelevant provided that data on position, time and the variable to be studied can be obtained. In such cases the biological meaning of the movement of the carrier is ignored. We believe this approach to be morally unacceptable. A second level is to consider that the equipped animal should behave 'normally' and thus demonstrate some reason- able state of well-being. It is within this framework that most seabird researchers work, although there are obvious control problems associated with determining and defining 'normal' behaviour. A third level, seldom realised, is that the animal shows no apparent reaction at all to emplacement of the device. This situation would be ideal and, were it easily achieved, could even make a case for the study of marine environmental variables irrespective of consideration of the biology of the bird in question. It is to be hoped that the constant improvements being made in solid state technology will enable us to achieve the third level in future studies. For the present, however, researchers must work in a morally grey area where their drive to obtain new data must be, or should be, tempered by the ethics of bird exploitation. To safeguard the welfare of seabirds we suggest that no measurement of environmental variables using seabirds should take place unless those variables are directly considered with respect to the movement or behaviour of the equipped animals. This rule would act as a policing policy to ensure that the well-being of the seabird is of primary concern. Having implemented this, however, the simple fact 
that seabirds are strongly selected to exploit the marine environment as efficiently as possible, might lead us to expect that these remarkable animals have a great deal to tell us about an environment with which we are not really familiar.

\section{CONCLUSIONS}

Seabirds are fast-moving, wide-ranging, highly efficient top predators of oceanic ecosystems that exploit the upper layers of the water column. They are potentially excellent carriers of sophisticated remotesensing equipment from which bird positional information and data on the physical characteristics of the marine environment can be calculated. The precision with which bird position can be determined currently varies between about $150 \mathrm{~m}$ and $100 \mathrm{~km}$, and positional fixes can be taken over time scales ranging from seconds to days, being highly dependent on the system used. This situation will change dramatically as soon as GPS units are small enough to be deployed on seabirds so that positions can be determined to within a few metres and updated every second if the bird is at the surface. To date, temperature and light are the only environmental parameters which have been monitored via seabirds, although, given current advances in solid state technology, this situation is likely to change within the next few years to include salinity. The reaction time of the sensor used is critically important in considerations of its utility in such studies. Currently no commercially available temperature sensor reacts fast enough to be able to measure temperature as a function of depth in diving seabirds. Despite their qualities for use in environmental monitoring the ethics of using seabirds necessitates that their wellbeing be a primary consideration in studies of this ilk. To ensure that this be the case, we suggest that all such research efforts focus primarily on understanding the normal movements of the birds. This approach will tend to protect the animals from career-driven data acquisition at any cost and allow researchers to identify regions of the world's oceans that are considered by the birds themselves to be worthy of study.

Acknowledgements. This study was supported by the Deutsche Forschungsgemeinschaft (Wi 1023/2-1, Ga 617/1-1 \& 1-2), the Japanese Ministry for Education Science and Culture and the Institut Français de la Recherche et Technologie Polaire. Grateful thanks are also extended to Janos Hennecke for help in hot and cold waterbaths and to Tony Chater and company for slithering after irritated albatrosses to recover devices. Bob Furness and Claudia Eidtmann were also helpful in field work with northern fulmars while Gerrit Peters helped extensively in specific matters pertaining to limnology and oceanography.

\section{LITERATURE CITED}

Adams NJ, Walter CB (1993) Maximum diving depths of Cape gannets. Condor 95:734-736

Argos User Manual (2000) Guide to the Argos System. CLS, Toulouse

Ashmole NP (1971) Seabird ecology and the marine environment. In: Farner DS, King JR (eds) Avian biology. Academic Press, New York, p 224-271

Bannasch R, Wilson RP, Culik BM (1994) Hydrodynamic aspects of design and attachment of a back-mounted device in penguins. J Exp Biol 194:83-96

Barrett RT, Furness RW (1990) The prey and diving depths of seabirds on Hornøy, North Norway after a decrease in the Barents Sea capelin stocks. Ornis Scand 21:179-186

Becker PH, Frank D, Sudmann SR (1993) Temporal and spatial pattern of Common Tern (Sterna hirundo) foraging in the Wadden Sea. Oecologia 93:389-393

Beckmen KB, Ylitalo GM, Towell RG, Krahn MM, O'Hara TM, Blake JE (1999) Factors affecting organochlorine contaminant concentrations in milk and blood of northern fur seal (Callorhinus ursinus) dams and pups from St. George Island, Alaska. Sci Total Environ 231:183-200

Benvenuti S (1993) Bird-borne satellite transmitters: current limitations and future prospects. Avocetta 17:35-39

Benvenuti S, Bonadonna F, Dall'Antonia L, Gudmundsson GA (1998) Foraging flights of breeding thick-billed murres (Uria lomvia) as revealed by bird-borne direction recorders. Auk 115:57-66

Bethge P, Nicol S, Culik BM, Wilson RP (1997) Diving behaviour and energetics in breeding Little Penguins (Eudyptula minor). J Zool 242:483-502

Birot D, Le Bris N, Leildé B, Menut E, Rolin JF, Caprais JC, Khripounoff A, Sarradin PM, Blain S, Floch J (1998) A multipurpose submersible chemical analyser for various applications in the marine environment. In: Proc Oceans '98 Conf. Institute of Electrical and Electronic Engineers Inc., Piscataway, NJ

Birt VL, Birt DP, Goulet D, Cairns DK, Montevecchi WA (1987) Ashmole's halo: direct evidence for prey depletion by a seabird. Mar Ecol Prog Ser 40:205-208

Block BA, Dewar H, Williams T, Prince ED, Farwell C, Fudge D (1998) Archival tagging of Atlantic bluefin tuna (Thunnus thynnus thynnus). Mar Technol Soc J 32:3746

Bost CA, Georges JY, Guinet C, Cherel Y, Pütz K, Charrassin JB, Handrich Y, Zorn T, Lage J, Le Maho Y (1997) Foraging habitat and food intake of satellite-tracked king penguins during the austral summer at Crozet Archipelago. Mar Ecol Prog Ser 150:21-33

Boyd IL (1997) Electronic marine mammals. Trends Ecol Evol $12: 327-328$

Bramanti M, Dall'Antonia P, Papi F (1988) A new technique to monitor the flight paths of birds. J Exp Biol 134:467-472

Brothers N, Gales R, Hedd A, Robertson G (1998) Foraging movements of the shy albatross Diomedea cauta breeding in Australia; implications for interactions with long-line fisheries. Ibis 140:446-457

Brown RGB, Bourne WRP, Wahl TR (1978) Diving by shearwaters. Condor 80:123-125

Burger AE (1990) Maximum diving depths and underwater foraging in alcids and penguins. In: Montevecchi WA, Gaston AJ (eds) Behavioural, ecological and oceanographic influences on the feeding ecology of marine birds. Can Wildl Serv Occas Pap 68

Burger AE, Powell DW (1990) Diving depths and diet of Cassin's Auklet at Reef Island, British Columbia. Can J Zool 68:1572-1577 
Burger AE, Simpson M (1986) Diving depths of Atlantic puffins and common murres. Auk 103:828-830

Burger AE, Wilson RP, Garnier D, Wilson MP (1994) Diving depths, diet and underwater foraging of Rhinoceros Auklets in British Columbia. Can J Zool 71:2528-2540

Burns JM, Castellini MA (1998) Dive data from satellite tags and time-depth recorders: a comparison in Weddell Seal pups. Mar Mamm Sci 14:750-764

Cairns DK (1987) Seabirds as indicators of marine food supplies. Biol Oceanogr 5:261-271

Cairns DK, Schneider DC (1990) Hot spots in cold water: feeding habitat selection by thick-billed murres. Stud Avian Biol 14:52-60

Calvo B, Furness RW (1992) A review of the use and the effects of marks and devices on birds. Ringing Migr 13: 129-151

Campaña C, Rivas AL, Marin MR (2000) Temperature and depth profiles recorded during dives of elephant seals reflect distinct ocean environments. J Mar Syst 24: 299-312

Camphuysen CJ (1995) Herring Gull Larus argentatus and lesser black-backed gull $L$. fuscus feeding at fishing vessels in the breeding season: competitive scavenging versus efficient flying. Ardea 83:365-380

Catard A, Weimerskirch H (1999) Satellite tracking of Whitechinned Petrel and comparison with other Procellariiformes. In: Adams N, Slotow R (eds) Proc 22nd Int Ornithol Congr (Durban, South Africa). University of Natal, Durban, p 3008-3023

Charrassin JB, Kato A, Handrich Y, Sato K, Naito Y, Ancel A, Bost CA, Gautheir-Clerc M, Ropert-Coudert Y, Le Maho Y (2000) Feeding behaviour of free-ranging penguins determined by oesophageal temperature. Proc R Soc Lond B Biol Sci 268:151-157

Chastel O (1994) Maximum diving depths of common diving petrels Pelecanoides urinatrix at Kerguelen Islands. Polar Biol 14:211-213

Clowater JS, Burger AE (1994) The diving behaviour of Pigeon Guillemots (Cepphus columbia) off southern Vancouver Island. Can J Zool 72:863-872

Croll DA, Gaston AJ, Burger AE, Konnoff D (1992) Foraging behavior and physiological adaptation for diving in thickbilled murres. Ecology 73:344-356

Croxall JP, Naito Y, Kato A, Rothery P, Briggs DR (1991) Diving patterns and performance in the Antarctic blueeyed shag Phalacrocorax atriceps. J Zool 225:177-199

Croxall JP, Davis LS (1999) Penguins: paradoxes and patterns. Mar Ornithol 27:1-12

Culik BM, Wilson RP, Bannasch R (1994) Underwater swimming at low energetic cost by pygoscelid penguins. J Exp Biol 197:65-78

Davis LS, Miller GD (1992) Satellite tracking of Adélie penguins. Polar Biol 12:503-506

Davis LS, Boersma PD, Court GS (1996) Satellite telemetry of the winter migration of Adélie penguins (Pygoscelis adeliae). Polar Biol 16:221-225

Davis RW, Fuiman LA, Williams TM, Collier SO, Hagey WP, Kanatous SB, Kohin S, Horning M (1999) Hunting behavior of a marine mammal beneath the Antarctic fast ice. Science 283:993-996

del Hoyo J, Elliott A, Sargatal J (1992) Handbook of the birds of the world, Vol 1. Ostrich to ducks. Lynx Edicions, Barcelona

del Hoyo J, Elliott A, Sargatal J (1996) Handbook of the birds of the world, Vol 3. Hoatzin to auks. Lynx Edicions, Barcelona

Delong RL, Stewart BS, Hill RD (1992) Documenting migra- tions of elephant seals using day length. Mar Mamm Sci 8:155-159

Duffy DC (1983) The foraging ecology of Peruvian seabirds. Auk 100:800-810

Falk K, Moller S (1995) Satellite tracking of high-arctic Northern Fulmars. Polar Biol 15:495-502

Falk K, Benvenuti S, Dall'Antonia L, Kampp K, Ribolini A (1999) Time allocation and foraging behaviour of chickrearing Brünnich's Guillemots Uria lomvia in high-arctic Greenland. Ibis 142:82-92

Furness RW, Camphuysen CJ (1997) Seabirds as monitors of the marine environment. ICES J Mar Sci 54:726-737

Garthe S (1997) Influence of hydrography, fishing activity, and colony location on summer seabird distribution in the south-eastern North Sea. ICES J Mar Sci 54:566-577

Garthe S, Grémillet D, Furness RW (1999) At-sea-activity and foraging efficiency in chick-rearing northern gannets Sula bassana: a case study in Shetland. Mar Ecol Prog Ser 185: 93-99

Garthe S, Benvenuti S, Montevecchi WA (2000) Pursuit plunging by northern gannets (Sula bassana) feeding on capelin (Mallotus villosus). Proc R Soc Lond B Biol Sci 267: $1717-1722$

Gaston AJ, Jones IL (1998) The auks. Bird families of the world. Oxford University Press, Oxford

Gaston AJ, Nettleship DN (1981) The thick-billed murres of Prince Leopold Island. Can Wildl Serv Monogr Ser 6

Georges JY, Guinet C, Jouventin P, Weimerskirch H (1997) Satellite tracking of seabirds: interpretation of activity pattern from the frequency of satellite location. Ibis 139: 403-405

Georges JY, Bonnadonna F, Guinet C (2000) Foraging habitat and diving activity of lactating fur seals in relation to sea surface temperatures at Amsterdam Island. Mar Ecol Prog Ser 196:291-304

Grémillet D (1997) Catch per unit effort, foraging efficiency and parental investment in breeding great cormorants (Phalacrocorax carbo carbo). ICES J Mar Sci 54:635-644

Grémillet D, Argentin G, Schulte B, Tulip BM (1998) Flexible foraging techniques in breeding Cormorants Phalacrocorax carbo and Shags Phalacrocorax aristotelis: benthic or pelagic feeding? Ibis 140:113-119

Grémillet D, Wilson RP, Storch S, Gary Y (1999) Threedimensional space utilization by a marine predator. Mar Ecol Prog Ser 183:263-273

Grémillet D, Wilson RP, Wanless S, Chater T (2000) Black browed albatrosses, international fisheries and the Patagonian Shelf. Mar Ecol Prog Ser 195:269-280

Hatch SA, Meyers PM, Mulcahy DM, Douglas DC (2000) Performance of implantable satellite transmitters in diving seabirds. Waterbirds 23:84-94

Harper PC (1987) Feeding behaviour and other notes on 20 species of Procellariiformes at sea. Notornis 34:169-192

Heath RJM, Randall RM (1989) Foraging ranges and movements of jackass penguins (Spheniscus demersus) established through radio telemetry. J Zool 217:367-379

Hedenström A, Alerstam T (1995) Optimum flight speed of birds. Philos Trans R Soc Lond B Biol Sci 348:471-487

Hill RD (1994) Theory of geolocation by light levels. In: Le Boeuf BJ, Laws RM (eds) Elephant seals: population ecology, behavior, and physiology. University of California Press, Berkeley, p 227-236

Hochscheid S, Wilson RP (1999) A new method for the determination of at-sea activity in sea turtles. Mar Ecol Prog Ser 185:293-296

Hochscheid S, Godley BJ, Broderick AC, Wilson RP (1999) Reptilian diving: highly variable dive patterns in the 
green turtle (Chelonia mydas). Mar Ecol Prog Ser 185: $101-112$

Huin N (1994) Diving depths of white-chinned petrels. Condor 96:1111-1113

Hull CL (1997) The effect of carrying devices on breeding royal penguins. Condor 99:530-34

Hull CL, Hindell MA, Michael K (1997) Foraging zones of royal penguins, and their association with oceanographic features. Mar Ecol Prog Ser 153:217-228

Hunt GL, Piatt J, Erikstad KE (1990) How do foraging seabirds sample their environment? In: Proc 20th Int Ornithol Congr (Christchurch, New Zealand). New Zealand Ornithological Congress Trust Board, Wellington, p 2272-2280

Hunt GL, Mehlum F, Russell RW, Irons D, Decker MB, Becker $\mathrm{PH}$ (1999) Physical processes, prey abundance, and the foraging ecology of seabirds. Proc of the 22nd Int Ornithol Congr (Durban, South Africa). University of Natal, Durban, p 2040-2056

Hutchinson LV, Wenzel BM, Stager KE, Tedford BL (1984) Further evidence for olfactory foraging by Sooty Shearwaters and Northern Fulmars. In: Nettleship DN, Sanger GA, Springer PF (eds) Marine birds: their feeding ecology and commercial fisheries relationships. Canadian Wildlife Service Special Publications, p 72-77

Irons DB (1998) Foraging area fidelity of individual seabirds in relation to tidal cycles and flock feeding. Ecology 79: $647-655$

Jerlov NG (1976) Marine optics. Elsevier Scientific Publications, Amsterdam

Johnsgard PA (1993) Cormorants, Darters, and Pelicans of the world. Smithsonian Institution Press, Washington

Jouventin P, Weimerskirch H (1990) Satellite tracking of Wandering Albatrosses. Nature 232:746-748

Jouventin P, Capdeville D, Cuenot-Chaillet F, Boiteau C (1994) Exploitation of pelagic resources by a non-flying seabird: satellite tracking of the king penguin throughout the breeding season. Mar Ecol Prog Ser 106:11-19

Kaplan ED (ed) (1996) Understanding GPS: principles and applications. Artech House Inc., Norwood, MA

Kato A, Watanuki Y, Naito Y (1998) Benthic and pelagic foraging of two Japanese Cormorants, determined by simultaneous recording of location and diving activity. Journal of the Yamashina Institute of Ornithology 30:101-108

Kenward RE (1987) Wildlife radio tagging. Academic Press, San Diego, CA

Kooyman GL, Kooyman TG (1995) Diving behavior of emperor penguins nurturing chicks at Coulman Island, Antarctica. Condor 97:536-549

Kooyman GL, Cherel Y, Le Maho Y, Croxall JP, Thorson PH, Ridoux V, Kooyman CA (1992) Diving behavior and energtics during foraging cycles in king penguins. Ecol Monogr 62:143-163

Koudil M, Cahrrassin JB, Le Maho Y, Bost CA (2000) Seabirds as monitors of upper ocean thermal structure: king penguins at the Antarctic Polar Front, east of Kerguelen sector. CR Acad Sci Paris 323(III):377-384

Le Corre M (1997) Diving depths of two tropical Pelicaniformes: the Red-tailed Tropicbird and the red-footed booby. Condor 99:1004-1007

Lishman GS (1985) The food and feeding ecology of Adélie penguins (Pygoscelis adeliae) and Chinstrap penguins $(P$. antarctica) at Signy Island, South Orkney Islands. J Zool 205:245-263

Longhurst A (1998) Ecological geography of the ocean. Academic Press, San Diego

McCafferty DJ, Boyd IL, Walker TR, Taylor RI (1999) Can marine mammals be used to monitor oceanographic conditions? Mar Biol 134:387-395

Meyers PM, Hatch SA, Mulcahy DM (1998) Effect of implanted satellite transmitters on the nesting behavior of murres. Condor 100:172-174

Monaghan P (1996), Relevance of the behaviour of seabirds to the conservation of marine environments. Oikos 77 : 227-237

Montevecchi WA (1993) Birds as indicators of change in marine prey stocks. In: Furness RW, Greenwood JJD (eds) Birds as monitors of environmental change. Chapman \& Hall, London, p 217-66

Montevecchi WA, Myers RA (1996) Dietary changes of seabirds indicate shifts in pelagic food webs. Sarsia 80: 313-322

Morris RD, Black JE (1980) Radiotelemetry and herring gull foraging patterns. J Field Ornithol 51:110-118

Mossner S, Ballschmiter K (1997) Marine mammals as global pollution indicators for organochlorides. Chemosphere 34 : 1285-1296

Nel DC, Nel JL, Ryan PG, Klages NTW, Wilson RP, Robertson G (2000) The foraging ecology of greyheaded mollymawks at Marion Island: in relation to known longline fishing activity. Biol Conserv 96:219-231

Nevitt GA, Veit RR, Kareiva P (1995) Dimethyl sulphide as a foraging cue for Antarctic procellariiform seabirds. Nature 376:680-682

Oka N (1994) Underwater feeding of three shearwaters: pale footed (Puffinus carneipes), sooty (Puffinus griseus) and streaked (Calonectris leucomelas) shearwaters. J Yamashina Inst Ornithol 26:81-84

Orians GH, Pearson NE (1979) On the theory of central place foraging. In: Horn DJ, Mitchell RD, Stairs GR (eds) Analysis of ecological systems. Ohio State University Press, Columbus, p 154-177

Ostrand WD, Drew GS, Suryan RM, McDonald LL (1998) Evaluation of radio-tracking and strip transect methods for determining foraging ranges of black-legged kittiwakes. Condor 100:709-718

Pearson TH (1968) The feeding biology of seabird species breeding on the Farne Islands, Northumberland. J Anim Ecol 37:521-552

Pennycuick CJ (1982) The flight of petrels and albatrosses (Procellariiformes) observed in South Georgia and its vicinity. Phil Trans R Soc Lond B Biol Sci 300:75-106

Pennycuick CJ (1997) Actual and 'optimum' flight speeds: field data reassessed. J Exp Biol 200:2355-2361

Peters G, Wilson RP, Scolaro JA, Laurenti S, Upton J, Gallelli $\mathrm{H}$ (1998) The diving behavior of the Magellanic penguin (Spheniscus magellanicus) at Punta Norte, Peninsula Valdes, Argentina. Colon Waterbirds 21:1-10

Pinshow B, Fedak MA, Schmidt-Nielsen K (1977) Terrestrial locomotion in penguins: it costs more to waddle. Science 195:592-594

Pond S, Pickard GL (1983) Introductory dynamical oceanography. Pergamon Press, Oxford

Prince PA, Jones M (1992) Maximum dive depths attained by South Georgia diving petrel Pelecanoides georgicus at Bird Island, South Georgia. Antarct Sci 4:433-434

Prince PA, Huin N, Weimerskirch H (1994) Diving depths of albatrosses at South Georgia and Macquarie Islands. Antarct Sci 6:353-354

Prince PA, Croxall JP, Trathan PN, Wood AG (1998) The pelagic distribution of South Georgia albatrosses and their relationships with fisheries. In: Robertson G, Gales R (eds) Albatross biology and conservation. Surrey Beatty \& Sons, Chipping Norton, p 137-167 
Pütz K, Wilson RP, Charrassin JB, Raclot T, Lage J, Le Maho Y, Kierspel MAM, Culik BM, Adelung D (1998) Foraging strategy of king penguins (Aptenodytes patagonicus) during summer at the Crozet Islands. Ecology 79:1905-1921

Pütz K, Ropert-Coudert Y, Charassin JB, Wilson RP, Le Maho $\mathrm{Y}$ (1999) Foraging areas of breeding king penguins (Aptenodytes patagonicus) in the southern Indian Ocean. Mar Ornithol 27:77-84

Robertson GG (1995) The foraging ecology of emperor penguins (Aptenodytes forsterii) at two Mawson Coast colonies, Antarctica. Aust Nat Antarct Res Exped Rep 138:1-139

Ryan PG, Nel DC (1998) Foraging behaviour of diving petrels Pelecanoides. Emu 98:1-3

Schreer JF, Testa JW (1996) Classification of Weddell Seal diving behaviour. Mar Mamm Sci 12:227-250

Schreiber RW, Woolfenden GE, Curtsinger WE (1975) Prey capture by the brown pelican. Auk 92:649-654

Service Argos (1996) User's manual. Argos/CLS, Landover, MD

Sisak MM (1998) Animal-borne GPS and the deployment of a GPS based archiving datalogger on Hawaiian monk seal. Mar Technol Soc J 32:30-36

Skira I (1979) Underwater feeding by short-tailed shearwaters. Emu 79:43

Spinrad RW, Carder KL, Perry MJ (eds) (1994) Ocean optics. Oxford University Press, New York

Storch S, Hillis-Star ZM, Wilson RP (in press) Things to do, places to be: internesting diving behavior of Caribbean hawksbill turtles elucidated through archival tags. Proc 20th Annu Symp Sea Turtle Biol Conserv, Orlando, Texas

Sturlaugsson J, Johannsson M (1996) Migratory pattern of wild sea trout (Salmo trutta L.) in SE-Iceland recorded by data storage tags. ICES CM M:5:1-16

Taillade M (1992) Animal tracking by satellite. In: Priede IM, Swift SM (eds) Wildlife telemetry: remote monitoring and tracking of animals. Ellis Horwood, Chichester, p 149-160)

Tyler JE (1968) The Secchi disc. Limnol Oceanogr 13:1-6

Tyler JE (ed) (1977) Light in the sea. Benchmark Papers in Optics 3, Stroudsburg

von Hünerbein K, Hamann HJ, Rüter E, Wiltschko W (2000) A GPS-based system for recording the flight paths of birds. Naturwissenschaften 87:278-279

Wanless S, Harris MP (1992) At-sea activity budgets of a pursuit-diving seabird monitored by radio telemetry. In: Priede IG, Swift SM (eds) Wildlife telemetry: remote monitoring and tracking of animals. E. Horwood, Chichester, p 591-598

Wanless S, Harris MP, Morris JA (1985) Radio-monitoring as a method for estimating time budgets of Guillemots Uria aalge. Bird Study 32:170-175

Wanless S, Harris MP, Morris JA (1991) Foraging ranges and feeding locations of Shags Phalacrocorax aristotelis during chick rearing. Ibis 133:30-36

Wanless S, Corfield T, Harris MP, Buckland ST, Morris JA (1993) Diving behaviour of the shag Phalacrocorax aristotelis (Aves: Pelecaniformes) in relation to water depth and prey size. J Zool 231:11-25

Wanless S, Finney SK, Harris MP, McCafferty DJ (1999) Effect of the diel light cycle on the diving behaviour of two bottom feeding marine birds: the blue-eyed shag Phalacrocorax atriceps and the European shag P. aristotelis. Mar Ecol Prog Ser 188:219-224

Watanaki Y, Mori Y, Naito Y (1992) Adélie penguin parental activities and reproduction: effects of device size and timing of its attachment during chick rearing. Polar Biol 12: 539-544

Watanuki Y, Kato A, Naito Y (1996) Diving performance of male and female Japanese Cormorants. Can J Zool 74: 1098-1109

Weimerskirch H (1998a) Foraging strategies of Indian Ocean albatrosses and their relationships with fisheries. In: Robertson G, Gales R (eds) Albatross biology and conservation. Surrey Beatty \& Sons, Chipping Norton, p 168-179

Weimerskirch H (1998b) Breeding and foraging decisions in petrels and albatrosses. Ostrich 69:64

Weimerskirch H, Wilson RP (1992) When do wandering albatrosses Diomedea exulans forage? Mar Ecol Prog Ser 86: 297-300

Weimerskirch H, Wilson RP (2000) Oceanic respite for wandering albatrosses. Nature 406:955-956

Weimerskirch H, Salamolard M, Jouventin P (1992) Satellite telemetry of foraging movements in the wandering albatross. In: Priede IG, Swift SM (eds) Wildlife telemetry: remote monitoring and tracking of animals. Ellis Horwood, Chichester, p 185-198

Weimerskirch H, Salamolard M, Sarrazin F, Jouventin P (1993) Foraging strategy of wandering albatrosses through the breeding season: a study using satellite telemetry. Auk 110:325-342

Weimerskirch H, Doncaster P, Cuenot Chaillet F (1994) Pelagic seabirds and the marine environment: foraging of wandering albatrosses in relation to the availability and distribution of their prey. Proc R Soc Lond B Biol Sci 255: 91-97

Weimerskirch H, Wilson RP, Koudil M (1995) The use of seabirds to monitor sea surface and validate satellite remotesensing measures in the southern ocean. Mar Ecol Prog Ser 126:299-303

Weimerskirch H, Wilson RP, Lys P (1997) Activity pattern of foraging in the wandering albatross: a marine predator with two modes of prey searching. Mar Ecol Prog Ser 151:245-254

Weimerskirch H, Catard A, Prince PA, Cherel Y, Croxall JP (1999) Foraging white-chinned petrels Procellaria aequinoctialis at risk: from the tropics to Antarctica. Biol Conserv 87:273-275

Welch DW, Eveson JP (1999) An assessment of light-based geoposition estimates from archival tags. Can J Fish Aquat Sci 56:1317-1327

White GC, Garrott RA (1990) Analysis of wildlife radio-tracking data. Academic Press Inc. and Harcourt Brace Jovanovich Publishers, San Diego and Toronto

Wilson AD (1999) Using marine mammals when technology fails. Sea Technol 40:61-63

Wilson RP (1992) Environmental monitoring with seabirds: do we need additional technology? S Afr J Mar Sci 12: 919-926

Wilson RP (1995) The foraging ecology of penguins. In: Williams TD (ed) Penguins. Oxford University Press, Oxford, p 81-106

Wilson RP (2001) Beyond rings in birds for determination of movements; whither the archival tag? Ardea 89:231-240

Wilson RP, Culik BM (1992) Packages on penguins and device-induced data. In: Priede IM, Swift SM (eds) Wildlife telemetry: remote monitoring and tracking of animals. Ellis Horward, Chichester, p 573-580

Wilson RP, Peters G (1999) The foraging behaviour of the Chinstrap Penguin Pygoscelis antarctica at Ardley Island, Antarctica. Mar Ornithol 27:69-79

Wilson RP, Wilson MP (1988) Foraging behaviour in four sympatric cormorants. J Anim Ecol 57:943-955

Wilson RP, Wilson MP (1990) Foraging ecology of breeding Spheniscus penguins In: Davies LS, Darby J (eds) Penguin biology. Academic Press, San Diego, CA, p 181-206 
Wilson RP, Wilson MP, Link R, Mempel H, Adams NJ (1991) Determination of movements of African penguins using a compass system: dead reckoning may be an alternative to telemetry. J Exp Biol 157:557-564

Wilson RP, Ducamp JJ, Rees G, Culik BM, Niekamp K (1992a) Estimation of location: global coverage using light intensity. In: Priede IM, Swift SM (eds) Wildlife telemetry: remote monitoring and tracking of animals. Ellis Horward, Chichester, p 131-134

Wilson RP, Cooper J, Plötz J (1992b) Can we determine when marine endotherms feed: a case study with seabirds. J Exp Biol 167:267-275

Wilson RP, Culik BM, Bannasch R, Driesen HH (1993) Monitoring penguins at sea using data loggers. In: Biotelemetry XII. Proc 12th Int Symp Biotelemetry, Ancona, Italy. Editrice Universitaria Litografia Felici, Pisa, p 205-214

Wilson RP, Pütz K, Grémillet D, Culik BM, Kierspel M, Regel J, Bost CA, Lage J, Cooper J (1995a) Reliability of stomach temperature changes in determining feeding characteristics of seabirds. J Exp Biol 198:1115-1135

Wilson RP, Scolaro JA, Peters G, Laurenti S, Kierspel M, Gallelli, H, Upton J (1995b) Foraging areas of Magellanic penguins, Spheniscus magellanicus, breeding at San

Editorial responsibility: Otto Kinne (Editor),

Oldendorf/Luhe, Germany
Lorenzo, Argentina, during the incubation period. Mar Ecol Prog Ser 129:1-6

Wilson RP, Weimerskirch H, Lys P (1995c) A device for measuring seabird activity at sea. Avian Biol 26:172-175

Wilson R, Peters G, Culik B, Bannasch R (1996) Diving behaviour of gentoo penguins Pygoscelis papua; factors keeping dive profiles in shape. Mar Biol 126:153-162

Wilson RP, Pütz K, Peters G, Culik B, Scolaro JA, Charrassin JB, Ropert-Coudert Y (1997) Long term attachment of transmitting and recording devices to penguins and other seabirds. Wildl Soc Bull 25:101-106

Wilson RP, Alvarrez B, Latorre L, Adelung D, Culik B, Bannasch R (1998a) The movements of gentoo penguins Pygoscelis papua from Ardley Island, Antarctica. Polar Biol 19:407-413

Wilson RP, Culik BM, Kosiorik P, Adelung D (1998b) The over-winter movements of a chinstrap penguin. Polar Rec 34:107-112

Wilson RP, Rees G, Lage J, Pütz K, Kierspel MAM, Cooper J, Bost CA, Scolaro JA, Culik BM (in press) Determination of animal position at sea using changes in diel light intensity. Proc 5th Eur Conf Wildlife Telemetry. CNRS, Strasbourg

Submitted: January 23, 2001; Accepted: July 10, 2001

Proofs received from author(s): February 18, 2002 